P-ISSN : 1412-6141

E-ISSN : $2548-7744$

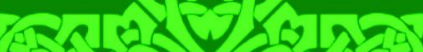
is 120 2ह

51030.

Muhammad Syahran

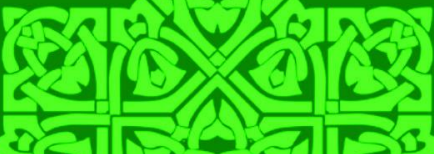
I of Humanities and Islamic Studies

(1) Al-Islām min Al-Ta'àlīm Ilā Al-Taṭbīqāt, Musykilat Al-Jisr Al-
Maqț'

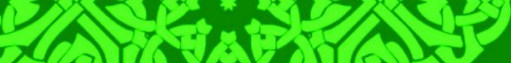

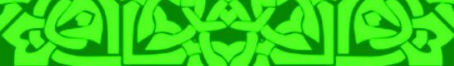

रति 03

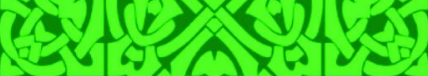

पer

(1)

Salafi and Social Religion Dynamics In Kendari

Muhammad Tahir Alibe, Abdul Muiz Amir

The Infallibility of The Prophet Muhammad Pbuh. As A Human Being (A Study Of His Ijtihad)

Muhammad Saleh Tajuddin The Role of Abdurrahman Wahid in Creating Islamic PostTraditionalist Paradigm in Indonesia

Muh Ilham Usman

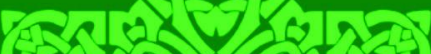

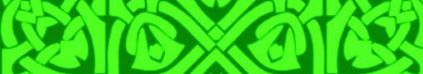
520

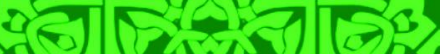
ff 20 is
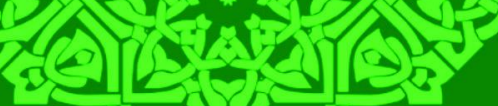

Cर ति 25 (a)

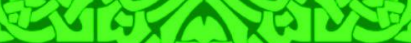
L in $\rightarrow$ Th

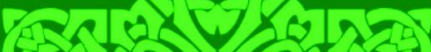
IC म 121 $1<$ 20

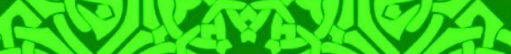

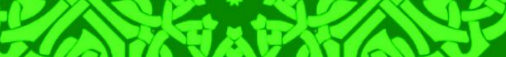

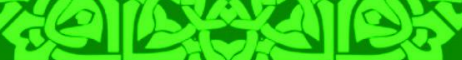

Tasmin Tangngareng, Hasbullah A Prophetic Study On Earthquake

Usman Jafar

Muslims' Thoughts of Non-Muslims' Political Rights in Majority Muslim Areas in Makassar 


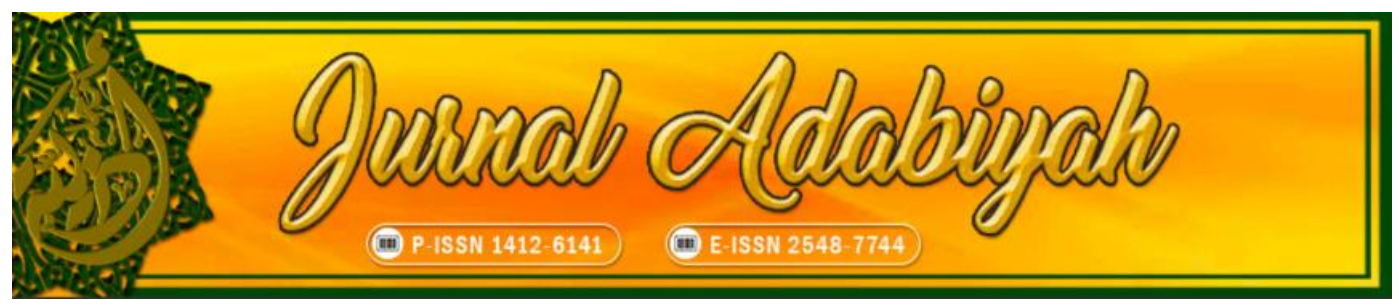

Thema: Islamic Studies

VOLUME 19 NO. 2 DESEMBER 2019

EDITOR-IN-CHIEF

Barsihannor, Alauddin State Islamic University, Indonesia

INTERNATIONAL EDITORIAL BOARD

Nuri Emmiyati, Alauddin State Islamic University, Indonesia

Minako Sakai, Australian National University (ANU), Australia

Abd Rauf Muhammad Amin, Fakulti Syariah Kupu SB Brunei Darussalam, Brunei Darussalam

Muhammad Zakir Husain, Universiti Islam Sultan Sharif Ali, Brunei Darussalam

Muhammad Widus Sempo, Universiti Sains Islam Malaysia, Malaysia

Salih Yousif Sharaf Mohamed, Al-Gazera University, Sudan

Aishah Waenaha Waemamah, Academy of Islamic and Arabic Studies Princess of Naradhiwas University - Thailand, Thailand

EXECUTIVE EDITOR

Umar Thamrin, Universitas Islam Negeri Alauddin, Indonesia

MANAGING EDITOR

Zaenal Abidin, Universitas Islam Negeri Alauddin

\section{EDITORS}

Rosmah Tami, Alauddin State Islamic University, Indonesia

Haniah, Alauddin State Islamic University, Indonesia

Nasrum, Alauddin State Islamic University, Indonesia

Awaluddin Syamsu, Universitas Muslim Indonesia

Ahmadi Usman, UIN Syarif Hidayatullah Jakarta, Indonesia

Baso Pallawagau, Alauddin State Islamic University, Indonesia Muhammad Azwar, Universitas Islam Negeri Syarif Hidayatullah Jakarta, Indonesia

Muh. Saleh Syamsuri, Alauddin State Islamic University, Indonesia

Andi Satrianingsih, Muhammadiyah University, Indonesia

Syahruni Junaid, Alauddin State Islamic University, Indonesia

Rabiatul Adawiah, Majene Islamic State College, West Sulawesi, Indonesia, Indonesia

Chusnul Chatimah Asmad, Alauddin State Islamic University, Indonesia

Nur Arifin, Alauddin State Islamic University, Indonesia

\section{IT SUPPORT}

Taufiq Mathar, Alauddin State Islamic University, Indonesia

\section{LANGUAGE ADVISOR}

Kustiwan Syarief, UIN Syarif Hidayatullah Jakarta, Indonesia

Muh. Saleh Syamsuri, Alauddin State Islamic University, Indonesia

\section{COVER DESIGNER}

Nur Arifin 


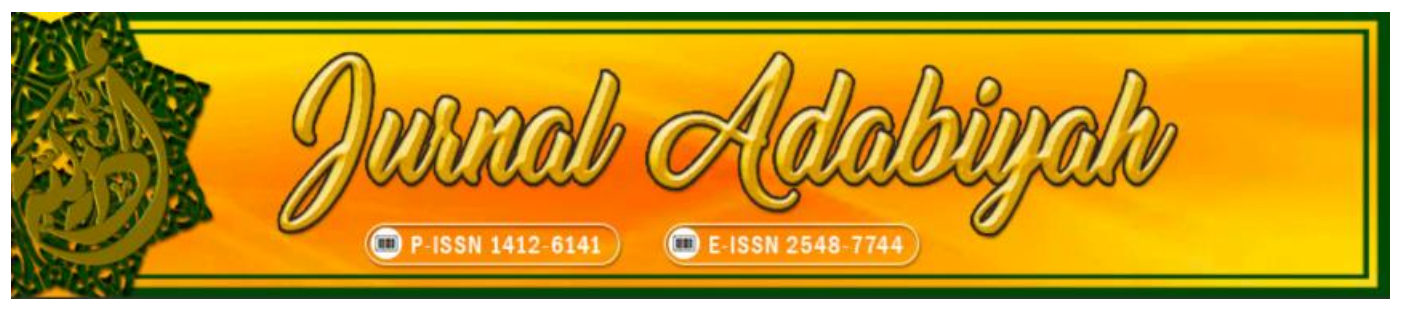

\section{Jurnal Adabiyah:}

This journal receives a national accreditation from Ministry of Research, Technology, and Higher Education Republic of Indonesia, Nomor 10/E/KPT/2019 on April 4, 2019 with the SINTA score: S2.

The Journal has been published by the Faculty of Adab and Humanity of Alauddin State Islamic University, Makassar, since 1997 and has been online since 2016 with the main themes on Humanities and Islamic Studies with the emphasis on interdisciplinary and intertextuality approach.

This journal are published twice a year, on June and December. The themes related to Islamic Studies are textual studies, scriptural traditions, Islamic law, and theology; and those related to Humanities are language, literature, history, and culture.

The journal of Humanities and Islamic Studies will provide the online collection of articles from 1997 up to now. The most updated information can be found on the website. 


\section{Table of Contents}

Muhammad Syahran

103-121

Al-Islām min Al-Ta'ālìm Ilā Al-Tațbīqāt, Musykilat Al-Jisr Al-Maqț'

Abbas

$122-136$

Salafi and Social Religion Dynamics in Kendari

Muhammad Tahir Alibe, Abdul Muiz Amir

137-156

The Infallibility of The Prophet Muhammad Pbuh. As A Human Being

(A Study Of His Ijtihad)

Muhammad Saleh Tajuddin

157-171

The Role of Abdurrahman Wahid in Creating Islamic Post-Traditionalist Paradigm in Indonesia

Muh Ilham Usman

172-185

Islam and Agrarian: Study of Nahdhatul Ulama's Religious Social Thought

Tasmin Tangngareng, Hasbullah

186-203

A Prophetic Study on Earthquake

Usman Jafar.

204-223

Muslims' Thoughts of Non-Muslims' Political Rights in Majority Muslim Areas in Makassar 


\title{
A PROPHETIC STUDY ON EARTHQUAKE
}

\author{
Tasmin Tangngareng \\ Faculty of Islamic theology, Philosophy, and Politics of \\ UIN Alauddin Makassar \\ Email: tasmin.tangngareng64@gmail.com \\ Hasbullah \\ Post Graduate Program of UIN Alauddin Makassar \\ Emai: hasbullah12ilha@gmail.com
}

\begin{abstract}
The phenomenon of earthquakes has become part of human's dark story within the history of the past people, in the current millennial era and it will still apply even to the end of the world. This article will discuss a study of earthquakes contained in the hadith of the Prophet (peace be upon him). In the history of prophethood, this phenomenon has occurred in Medina and even repeatedly experienced by the Prophet p.b.u.h. together with his faithful companions. This type of research is classified as qualitative using the approach of the science of hadith, theology, socio-historical and scientific. The complex discourse will come to vision with the implementation of two contrasting technical dialogues on the subject, namely those of the theological and the scientific views. The complexity of the convergence of the two lies in the detail that each had a circumstance in the prophetic era and is mentioned in the words of the Prophet p.b.u.h. The theological view believes that an earthquake is a punishment from the Creator owing to the decadence of morality in a society, whereas in a scientific perspective, an earthquake occurs because of the shift of the earth's plate which results in vibrations. Additionally, in the theological perspective, earthquakes are seen as parts of eschatology since there is a sign of their occurrence in the future mentioned in the hadith of the Prophet p.b.u.h. As for the theory of science, it is supported by the message of the Prophet p.b.u.h. that there is a geographical area with a high potential of earthquake strikes. Thus the discourse of the earthquake which has become a part of people's lives, as is also mentioned in the Prophet's hadith, will certainly come to pass for two main reasons, firstly it is related to the normative theological perspective and secondly, it is in accordance with the scientific studies.
\end{abstract}

Keywords: earthquake; theological views; scientific views; 


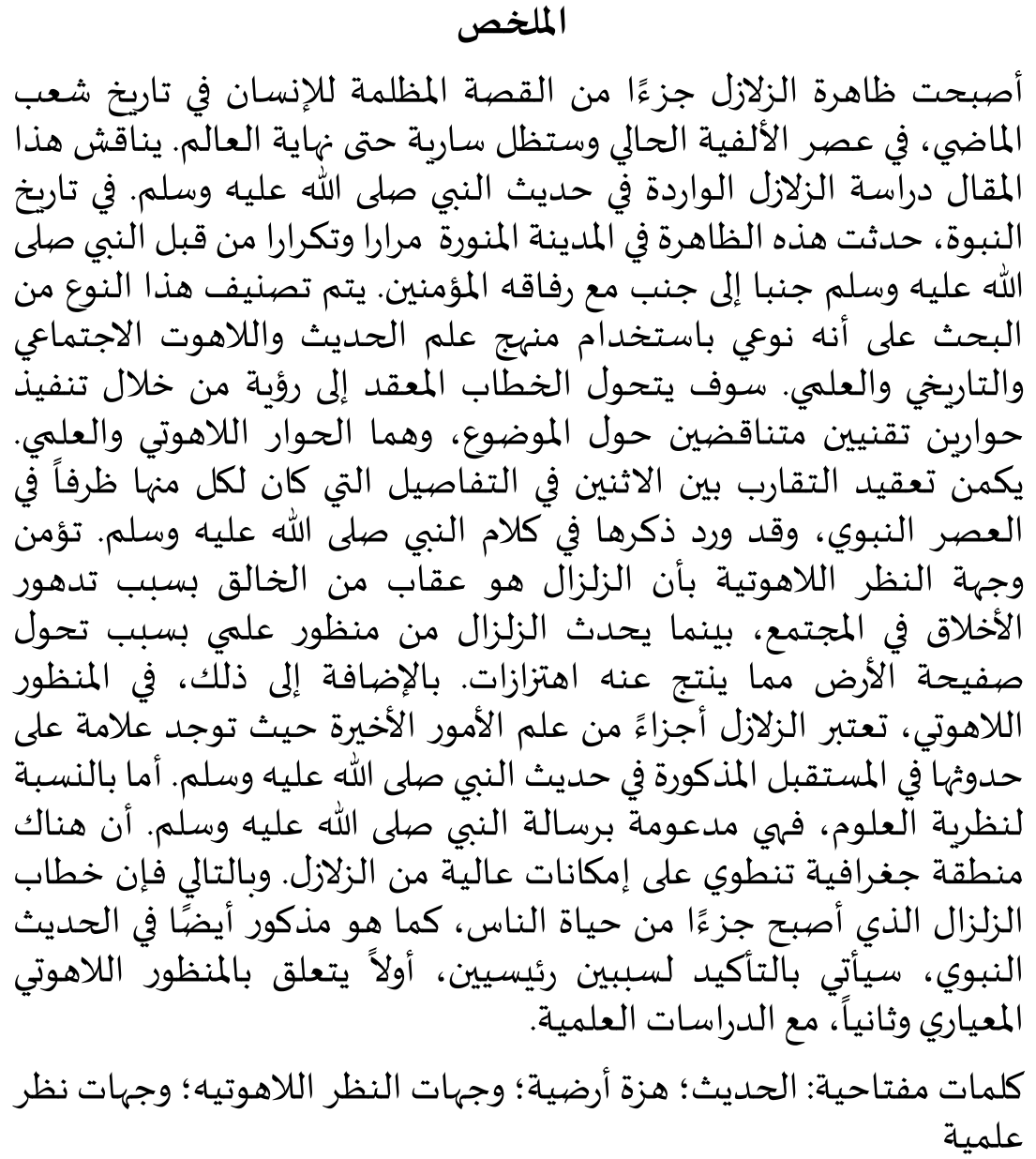

\begin{abstract}
Abstrak
Fenomena gempa bumi telah menjadi bagian dari sisi kelam kehidupan masyarakat, baik dalam sejarah umat-umat terdahulu sampai era milenial sekarang dan bahkan hingga menjelan hari kiamat. Artikel ini akan membahas sebuah studi gempa bumi yang terdapat dalam hadis Nabi saw., dalam sejarah kenabian fenomena ini pernah terjadi di Madinah bahkan berkali-kali dialami oleh Nabi saw. bersama dengan para sahabat. Jenis penelitian ini tergolong kualitatif dengan menggunakan pendekatan ilmu hadis, teologi, sosio-historis dan saintifik. Diskursus yang rumit pun akan lahir dengan pertentangan antara dua dialog keilmuan, yaitu pandangan teologi dengan pendekatan ilmiah (saintifik). Kerumitan konvergensi keduanya masingmasing mempunyai embrio yang pernah terjadi di era kenabian maupun disebut dalam sabda Sang Rasul. Pandangan teologi meyakini bahwa gempa sebagai azab dari Sang Pencipta disebabkan karena dekadansi moralitas dalam sebuah masyarakat. Sedangkan dalam perspektif saintis, gempa terjadi
\end{abstract}


karena pergeseran lempeng bumi yang mengakibatkan sebuah getaran. Masih dalam pandangan teologi, gempa bumi menjadi bagian dari eskatologi karena terdapat sebuah isyarat dalam hadis Nabi saw. bahwa gempa akan terjadi di masa yang akan datang, sementara pandangan sains yang didukung oleh pesan Nabi saw. bahwa terdapat sebuah daerah geografis yang rawan terjadi gempa bumi. Dengan demikian wacana gempa bumi yang telah menyatu dengan kehidupan masyarakat dalam diskursus hadis dapat dipastikan terjadi karena dua sebab pokok, berkaitan dengan teologi-normatif dan tidak terlepas dengan kajian ilmu pengetahuan (saitifik).

Kata Kunci: Hadis, gempa bumi, pandangan teologi dan saintifik

\section{A. Introduction}

The existence of hadith, which has been approved with divine legitimacy ${ }^{1}$, theoretically should provide solutions to every issue or humanitarian occasion as well as a phenomenon that occurs in the whole universe. The earth, with its vast oceans and lands, has gone through a wide range of strange natural symptoms that are not in accordance with its normal course, which is referred to as natural disasters. There are so many kinds of natural disasters occurring on earth, including earthquakes.

The phenomenon of earthquakes receives particular attention in the hadith discourse and hence makes an interesting subject to investigate further. Earthquake occurrences that came to pass the people of the earlier prophets have been told in the Quran, showing that a number of human civilizations were destroyed through natural disasters. $^{2}$ These incidents can be seen such as in the people of the Prophet Noah, who were wiped out with floods, the people of 'Ad a.s. who were destroyed with storm and thunder occurring for seven days and seven nights, and the people of

${ }^{1}$ The authority of the hadith comes from the Prophets p.b.u.h as he is as well a manifestation of the Qur'an. once Āishah r.a. was asked by a companion about the morality of the Prophet, she answered: khuluquh al-Qur'an. see, Abū al-Ḥusain Muslim ibn al-Hajjāj ibn Muslim al-Qusyairī alNaisābūrì, Sahīh Muslim, vol I (Bairūt; Dār al-Kutub al-'Ilmiyah, 1992 M.), p. 512-513. See, Abu 'Abd al-Raḥmān Ahmad ibn Syu'aib ibn 'Ali al-Khurāsānì al-Nasā'ì, al-Sunan al-Sagrī li al-Nasā'̄, Juz III (Halb; Maktab al-Mațbū'àt al-Islāmiyah, 1406 H/1986 M.), p. 199. See, Abū 'Abdillāh alHāakim Muḥammad ibn 'Abdillāh ibn Muḥammad ibn Ḥamdūyah ibn Nu'aim ibn Ḥakim al-Ḍabì alNaisābūri, Mustadrak 'alā al-Saḥiḥain, vol II (Bairūt: Dār al-Kutub al-'Ilmiyah, 1411 H/1990 M.), p. 670. See Arifuddin Ahmad, Metodologi Pemahaman Hadis Kajian Ilmu Ma'ānì al-Hadìs (Makassar: Alauddin University Press, 2013 M.), p. 1.

${ }^{2}$ The Qur'an informs about the history of ancient people and provide solutions to the occurring problems, provide explanations for issues unknown to human beings; see Muhammad Mahmud Hijazi, Fenomena Keajaiban al-Qur'an: Kesatuan Tema dalam al-Qur'an (Jakarta: Balai Pustaka, 2005 M.), p. 38. 
Prophet Lut a.s. who were destroyed with an earthquake. ${ }^{3}$ As in the words of Allah Almighty in QS al-'Ankabūt/29: 40.

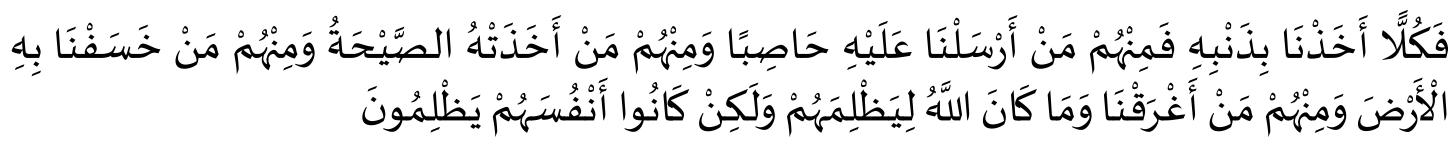

Translation:

Each one of them We seized for this crime: of them, against some We sent a violent tornado (with showers of stones); some were caught by a (mighty) blast; some We caused the earth to swallow up, and some We drowned (in the waters): it was not Allah Who injured (or oppressed) them: "They injured (and oppressed) their own souls.

The incidents revealed by the Qur'an as in the abovementioned explain the power of God over those who committed maltreatment. ${ }^{5}$ However, this does not imply that such incidents only befall the disobedient, for even the obedient are equally powerless to keep themselves away from disasters. In this case, the cause and effect assumption that earthquakes will only befall the people who carry out munkar or mistreatment should be left behind. The Prophet Muhammad saw. as an ideal Muslim model had also experienced earthquakes in his life, as related in Sahih alBukhārì.

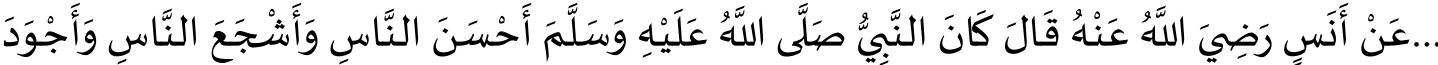

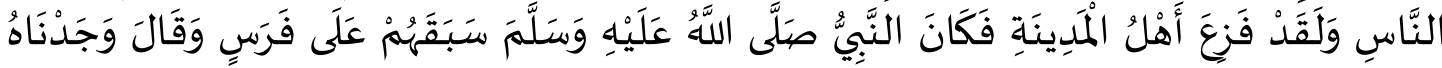
بَحْرًا (رواه البخَاري)

Translation:

...from Anas r.a. He said: The Prophet is the kindest, the most courageous and the most generous person. Indeed, an earthquake struck the inhabitants of Medina and the Prophet. The person who preceded them (in looking for the source of the earthquake) by riding a horse then reported: "We found out that it (the earthquake) was only the sea". (Related by al-Bukhäri)

An earthquake phenomenon is a disaster that normally brings about a range of damage and destruction that takes many lives. Earthquakes have been known for thousands of years. History has noted that the events of the first earthquake, which took place in China, occurred in $1177 \mathrm{BC}$. It is also recorded that throughout history,

${ }^{3}$ Kamarul Azmi Jasmi, Geologi Hidrologi, Oceanografi dan Astronomi dari Perspektif alQur'an (Malaysia: UTM Press, 2013 M.), p. 11.

${ }^{4}$ Kementerian Agama RI., al-Qur'an dan Terjemahnya, (Surabaya: Pustaka Assalam, 1431 H./2010 M.), p. 565.

${ }^{5}$ Earthquakes can occur because of some factors: purely God's will, humans' actions to their environment, and humans' sins. See Muhammad Makmun Abha, "Gempa Bumi dalam al-Qur'an (Tafsir Tematik)", Jurnal Esensia 14, no. 1 (April 2013): p. 29-31.

${ }^{6}$ Muḥammad ibn Ismā'īl Abū 'Abdillāh al-Bukhāri al-Ju'fì, Sahịh al-Bukhārī, vo IV (Dār alTauq al-Najāh, 1422 H.), p. 22. 
the strongest earthquake occurred in Chile on May 22, 1960, with a vibration strength of 9.5 on the Richter scale. ${ }^{7}$ Based on sources obtained from the U.S Geological Survey, the earthquake event was recorded in 1700 AD The earthquake event continued for more than twenty years. Furthermore, earthquake disasters become more frequent before the year $1800 \mathrm{AD}$ increases almost every year. Starting in 1890 earthquake events almost every year and sometimes the disaster took place several times in the same year. By the $20^{\text {th }}$-century, earthquake disasters were more frequent if earthquake events were recorded almost every month. This sort of incident is increasingly interesting to search further, bearing in mind another assumption that earthquakes can be taken as a sign for the coming of the end of time. Changes of the era are characterized by the ruin of social parameters, widespread chaos, and the occurrence of crimes as well as earthquakes everywhere. All these indicate the proximity of the end of the world, as often referred to by scholars as to the minor signs of the coming of the doomsday. ${ }^{8}$

\section{B. Research Methods}

\section{Types of research}

This research is classified as qualitative research by referring to literature such as books, journals, articles, and documents (library research). A literature study is needed as a preliminary stage (preliminary research) to understand the symptoms that develop in the field or in society.

2. Approach

The types of approaches used in this study are as follows:

a. Hadith approach

Hadith that are the object of study is the traditions about earthquakes, so this research first refers to the sourcebook of hadith to identify the traditions.

b. Theological Approach

Theology is the study of belief in God Almighty. His asthma and His attributes. This approach aims to prove the existence of a causal relationship between the occurrence of earthquakes with the quality of a community's confidence in the Creator.

c. Socio-historical approach

This approach aims to look at historical facts, past earthquake events and then reveal the meaning behind these events.

d. Scientific approach

The main activities in using a scientific approach, namely: first, exploring information can be done through reading, observing activities, events or objects. Second, Associating is done through data analysis activities. Third, convey the

${ }^{7}$ Noor Fazilah Mohd Basiron, "Fenomena Gempa Bumi: Tinjauan Awal Terhadap Kewujudannya dalam al-Qur'an", Jurnal Islam dan Masyarakat Kontemporari 9, (Januari 2015): p. 142.

${ }^{8}$ Dewan Redaksi, Ensiklopedi Islam Jakarta: PT Ichtiar Baru Van Hoeve, 1993 M.), p. 61-62. 
results of conceptualization. The scientific approach in this study aims to explain the characteristics of the geographic location of earthquake-prone areas as a form of an effort to anticipate and deal with disasters.

\section{Earthquake by definition}

The Prophet's hadith employ a number of terms that indicate earthquake events, such as zalzala, rajafa, tah arraka, faza'a and khasafa. In general, earthquakes are defined as shocks or vibrations that occur on the surface of the earth. These vibrations can be divided into several types according to the source and cause of their occurrences. Landslide earthquakes are earthquakes that occur from the interior holes of the earth, for example, due to collapses of mines or slides of rocks that cause earthquakes. ${ }^{9}$ Unbalanced conditions cause a shift to a denser position in order to fill out the interior holes that are empty or unevenly filled.

Volcanic earthquakes are earthquakes that occur due to volcanic activity. When the magma moves to the surface of the volcano, it moves and breaks the rocks and results in prolonged vibrations that can last from several hours to several days. ${ }^{10}$ Tectonic earthquakes are earthquakes that occur due to the release of a certain amount of energy when the earth's plates move ${ }^{11}$

\section{Earthquakes in a socio-historical context}

1. Earthquake events in the days of previous prophets

The earthquake described in the Koran first occurred during the time of Prophet Saleh as. His people were known as the people of Samud. As maintained by history, the incident occurred around 3900 years ago. People of Samūd lived in the country of Wadi al-Qura', which is dominated by mountains but is very fertile because many springs appear on the slopes of the mountains. High technical skills made them adept in building canals to drain water from the springs so that regular irrigation networks are developed. ${ }^{12}$ Like the people of 'Ad, however, they were also afflicted with some arrogant nature that they committed destructions. As a result, the wrath of Allah Almighty then fell upon them in the form of extremely big thunder lightning, which led to a great earthquake in Wadi al-Qura' area and the people of Sāmūd perished. ${ }^{13}$

${ }^{9}$ Agus Hendratno, "Kumpulan Materi: Pengenalan Bencana Alam Tanah Longsor" (Yogyakarta: PDF Program, 2007 M.).

${ }^{10}$ Arbiater Samariter Bund, Handout Kesiapan Sekolah dalam Menghadapi Bencana (Yogyakarta: Arbiater-Samariter-Bund, 2008 M.), p. 5.

${ }^{11}$ Arbiater Samariter Bund, Handout Kesiapan Sekolah dalam Menghadapi Bencana, p. 3.

${ }^{12}$ Ahmad Muhaimin ibn Mohd Zamri, “Relevansi Sains dengan Makna Zalzalah in al-Qur'an (Kajian Tafsir Tematik), Thesis (Riau: Fak. Ushuluddin UIN Sultan Syarif Kasim, 2013 M.), p. 25

${ }^{13}$ Dwi Ratnasari, “Sejarah Nabi-Nabi dalam al-Qur’an”, Komunika, Vol. 5, No.1, 2011, h. 98. Lihat juga: Abdurrahman, "Mukjizat al-Qur'an dalam Berbagai Aspeknya”, Jurnal Pusaka, Vol. 8, No. 
The great earthquake also happened to the people of the Prophet Lüt a.s., that is one of the branches of the Amalekit tribe that lived in Sham, more specifically around the Dead Sea Lake and its surrounding cities, including Sodom and Gomorah about 3800 years ago. These people refused to obey Allah's commands even though Prophet Lüt a.s. had been sen upon them. Exploitation and abuse (munkar) committed by people of this tribe were really beyond the limit. An instance of the set of circumstances was homosexuality. ${ }^{14}$ When the actions of munkar had been repeatedly committed and were widely practiced, God Almighty demolished them with harsh punishment in the form of a dreadful earthquake.

A devastating earthquake also occurred during the time of Prophet Syu'aib a.s. about 3600 years ago, which struck the Madyan tribe. the territory was located on the east coast of the Red Sea, bordering the Gulf of Aqabah in the north. This tribe was known as a group of people who made cheating in trading a common practice and had caused a great loss on other peoples. They were also known to be fierce and violent, as they did not hesitate to hijack and rob traders' caravans passing across their city. As the case of the previous tribes which Allah SWT destroyed, the Madyan tribe also held tightly to the religion of paganism. These people worshiped many idols. ${ }^{15}$

Such an incident also happened to the people of Prophet Musa a.s., namely the Israelites about 3200 years ago. After escaping from the kingdom of Pharaoh, the people of the great tribe Israel continued their journey across the Sinai Desert until they arrived at the foot of Mount T ürsina. This hill is located on the Sinai Peninsula, which is a vast land that juts into the Red Sea bordered by the Gulf of Suez on the west side and the Gulf of Aqabah on the east side. Here in Mount Tursina the prophet Musa a.s. was contemplating that he left the great tribe of Israel for some time. ${ }^{16}$

Then they were left alone during Prophet Musa's contemplation, a big part of these great tribes of Israel break their word from the religion of monotheism and converted to the religion of paganism in Egypt, worshiping a golden cow statue made by Samiri. When the prophet Musa a.s. returned and found out the practice of worshiping the cow statue, he was very angry. God ordered Prophet Musa a.s. to choose seventy people from his people and take them away to pray to their God. Among the prayers they requested was that they are given what was never given to

68, tahun 20016 (PDF Program, 2017), p. 73. Lihat; The story is revealed in the word of God Almighty in QS al-A'rā f/ 7: 78.

${ }^{14}$ Homoseksuality is an inclination to the same sex. See; Tim Penyusun Kamus Pusat Pemibnaan Bahasa Indonesia, Kamus Besar Bahasa Indonesia (Jakarta: Balai Pustaka, 1991 M.), p. 506.

${ }^{15}$ Ahmad Muhaimin ibn Mohd Zamri, "Relevansi Sains dengan Makna Zalzalah dalam alQur'an (Kajian Tafsir Tematik), Thesis, p. 29.

${ }^{16}$ Muh. Ma'ufin Sudibyo, Ensiklopedi Fenomena Alam dalam al-Qur'an (Solo: Tinta Medina, 2012 M.), p. 141. Dikutip dalam: Ahmad Muhaimin ibn Mohd Zamri, "Relevansi Sains dengan Makna Zalzalah dalam al-Qur' an (Kajian Tafsir Tematik), Thesis, p. 29. 
people before them and would not be given to people after them. God was not pleased with what they prayed for, and they were shaken by an earthquake. ${ }^{17} \ldots$.

2. Earthquake during the time of the Prophet p.b.u.h. and after

The accounts of earthquakes that have been told in the stories of the previous people were both in the forms of devastating disasters and of warning for mistakes that took place. This sort of incident also occurred at the time of the Prophet Muhammad p.b.u.h., as pictured in the hadith narrated by al-Bukhāri.

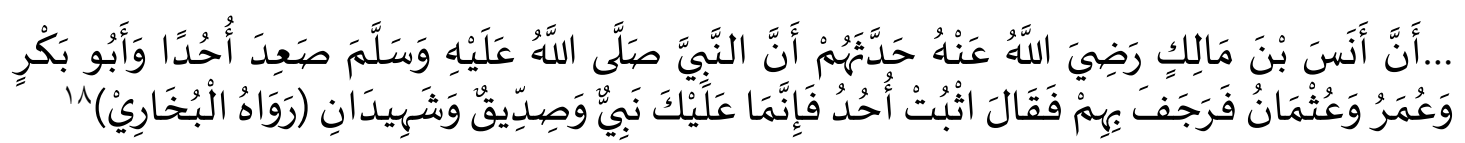

Translation:

...that Anas ibn Mālik r.a. told a story to them that the Prophet was climbing Mount Uhud, followed by Abu Bakr, 'Umar and 'Usman. Then the mountain Uhud was vibrating, so the Prophet said: "Calm down O Uhud, because above you there are now the Prophet saw., al-Siddiq (the truthful, which means Abu Bakr) and two people (who will die ) martyr". (Related by al-Bukhari).

The above hadith explains that there was an earthquake that was directly experienced by the Prophet saw. together with companions. The same incident was also experienced by Umar ibn al-Khattab during his caliphate era, as in the experience of Umar ibn Abd al-'Aziz in his reign. ${ }^{19}$ There have been a number of earthquakes occurring in Islamic history, earthquakes have become parts of the historical records and are no longer a new phenomenon faced by human beings. The occurrence of earthquakes after the era of the companions took place in 212 Hijrah, corresponding to year $827 \mathrm{AD}$, in Yemen. The same incident also occurred in the region of Aden, which took massive lives and properties. ${ }^{20}$

In addition, an earthquake also took place in 245 Hijriyah in Antokiyah, one of the regions in Turkey. The disaster took victims and caused a great loss, including 1500 residents' dwellings. ${ }^{21}$ Preceding earthquakes occurred in 242 Hijriyah or in

${ }^{17} \mathrm{Abu}$ al-Fidā' Ismāīil ibn 'Umar ibn Kas̄ir al-Qurasyī, Tafsìir al-Qur'ān al-'Azìim, vol III (Bairūt: Dār al-Kutub al-'Ilmiyah, 1419 H.), p. 431. See; Jalāl al-Dīn Muḥammad ibn Ahmad alMahalli dan Jalāl al-Dīn 'Abd al-Raḥmān ibn Abī Bakr al-Suyūṭi, Tafsīr Jalālain (Cet. I; al-Qāhirah: Dār al-Ḥadì̇, n. d.), p. 216. Lihat juga; Noor Fazilah Mohd Basiron dan Munirah Abd Razzak, "Fenomena Gempa Bumi: Tinjauan Awal Terhadap Kewujudannya dalam al-Qur'an" Jurnal Islam dan Masyarakat Kontemporari (PDF Program, 2015), p. 153.

${ }^{18}$ Muḥammad ibn Ismā'ìl Abū 'Abdillāh al-Bukhārì al-Ju’fí, Saḥịh al-Bukhārīi, vol V, p. 9.

${ }^{19}$ Syaikh 'Abd al-'Azīz ibn 'Abdullāh ibn Bāz, Nașịhah Haul al-Zalāzil, trans. Syafar Abu Difa, Nasehat Seputar Gempa (Islamhouse, 1430 H./2009 M.), p. 5.

${ }^{20} \mathrm{Abū}$ al-Ḥasan 'Ali ibn Abī al-Karim Muhammad ibn Muḥammad 'Abd al-Karim ibn 'Abd alWāhìid al-Syaibānī al-Jazirì 'Iz al-Dīn ibn al-As̄ìr, al-Kāmil fī al-Tārīkh, vol V (Bairūt: Libanōn, 1997 M.), p. 488

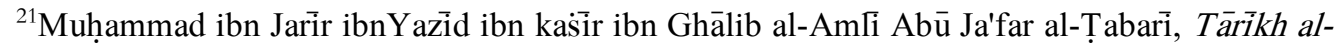
Rusul wa al-Muluk, vol IX (Bairūt: Dār al-Turāis, 1387 H.), p. 213. 
856 AD in Persia, Khurasan, and Sham, causing devastation and taking thousands of lives.

\section{E. Analysis of the Meanings of Earthquakes in Hadith Discourse}

1. Earthquakes as a natural phenomenon at the time of the Prophet

Natural phenomena can be taken as proofs of the presence of the Creator as well as proofs of His omnipotence. ${ }^{22}$ Natural laws, as the case of social laws, are general and definite. ${ }^{23}$ A devastating earthquake caused the ground to vibrate intensely due to the movement of the tectonic plates and the enormous chunks of rock that make up the surface of the earth. This event happened at the time of the Prophet saw. An earthquake with considerable strength shook Medina, as in the hadith related by al-Bukhari.

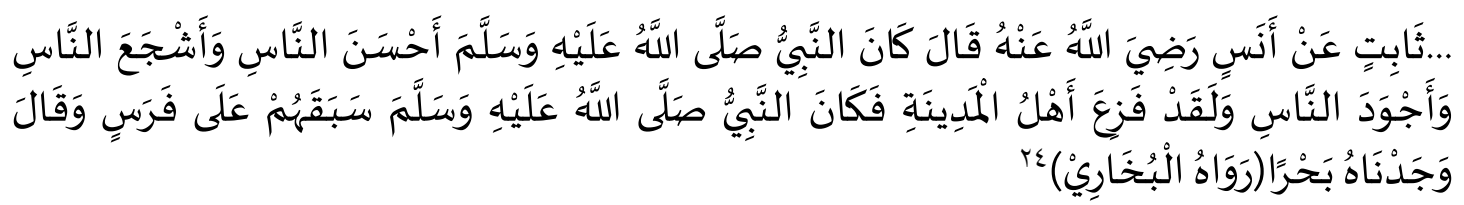

Translation:

...from Anas r.a. He said: The Prophet is the kindest, the most courageous and the most generous person. Indeed, an earthquake struck the inhabitants of Medina and the Prophet. The person who preceded them (in looking for the source of the earthquake) by riding a horse then reported: "We found out that it (the earthquake) was only the sea". (Related by al-Bukhari).

The above hadith states that there was an earthquake that rocked the residents of Medina. According to the researcher, the pronunciation needs to be interpreted textually, because the earthquake with vibrations that occurred on the surface of the earth actually happened and caused the residents of Medina panic. ${ }^{25}$ When the incident occurred, the Prophet saw, who was courageous by nature, preceded the inhabitants of Medina by riding Abu Talha's horse to find the point where the earthquake occurred. There was an interesting explanation about the

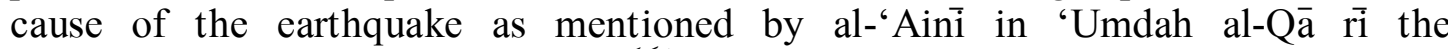
pronunciation of the phrase الدَّابَّة وركوب meant that the vibration was caused by the

${ }^{22}$ Kamus Besar Ilmu Pngetahuan, p. 28. See also; Bey Arifin, Mengenal Tuhan (Surabaya: PT. Bina ilmu, n.d..), p. 127-128. Natural phenomena showing the power of God for those who contemplate See; Choiruddin Hadhiri SP, Klasifikasi Kandungan al-Qur'an (Jakarta: Gema insani Press, 1993 M.), p. 51. Bandingkan dengan; Syaikh Muhammad Ali al-Sabauni, Gerak dan Rotasi Bumi (Jakarta: Dar al-Kutub al-Islamiyah, 2003 M.), p. 46.

${ }^{23}$ M. Quraish Shihab, Secercah Cahaya Ilahi Hidup Bersama al-Qur'an, Ed 2 (Bandung: Mizan, 1434 H./2013 M.), p. 477.

${ }^{24}$ Muḥammad ibn Ismā'il Abū ‘Abdillāh al-Bukhārì al-Ju’fî, Saḥịh al-Bukhārì, Juz IV, h. 22.

${ }^{25}$ Aḥmad ibn Muhammad ibn Abī Bakr ibn 'Abd al-Mālik al-Qasțalānī al-Qutaibì al-Miṣrī, Irsyād al-Sārī li al-Syarḥ Saḥịh al-Bukhārī, vol V (Mesir: al-Maṭba'ah al-Kubrā al-Amīriyah, 1323 H.), p. 54. 
rise of a gigantic reptile to the surface of the earth. ${ }^{26}$ Another account mentioned that there had been a battle between large animals under the ground and caused the surface of the earth to shake.

To the researcher's opinion, such an assumption is no longer acceptable in the current time and is incompatible with technological advances. Believing that earthquakes occur because of the release of large animals to the surface of the land or the sea was commonplace in ancient times. This understanding can not be separated from the socio-historical context that surrounded the society at that time. At that time, it was normal to believe that an earthquake was caused by forces outside the natural sciences. Furthermore, the researcher concludes that the hadith above explains a natural phenomenon experienced by the Prophet saw. so the hadith explanation must conform to the scientific truths of the development of science.

There are two types of earthquakes, namely tectonic earthquakes, and volcanic earthquakes. Tectonic earthquakes are caused by the release of energy that occurs due to the shifting of tectonic plates like the case of a rubber band that is pulled and suddenly released. The power generated by the pressure between rocks is known as tectonic defects. The theory of tectonic plate explains that the earth consists of several layers of rock, most of the area of the crust layer will be washed away and float in the layers like snow. The layer moves slowly that it breaks and collides with each other. This is what leads to a tectonic earthquake. Whereas volcanic earthquakes are caused by the movement of magma upwards in a volcano, wherein the shift of rocks produce earthquakes. ${ }^{27}$

2. Earthquakes indicate the miracle of the Prophet saw.

The incident experienced by the Prophet saw. along with some of the companions when climbing the mountain showed his privilege as a prophet of Allah the Almighty and the virtues of his companions who put themselves out with him. This incident tells us that the Prophet saw. together with the companion's experienced shocks or earthquakes while climbing Mount Uhud, as narrated in Sahih al-Bukhari.

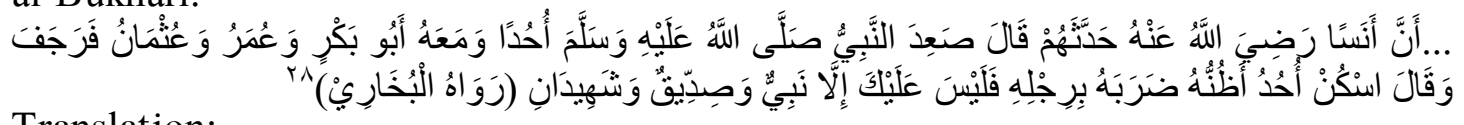

Translation:

...that Anas ibn_Mālik r.a. said: The Prophet was climbing Mount Uhud, followed by Abu Bakr, 'Umar and 'Usman. Then the mountain Uhud was vibrating, so the Prophet said: "Calm down O Uhud." As I recall he stamped his feet while saying: Because above is no other than the Prophet saw., alSiddiq, (the truthful, which means Abu Bakr) and two people (who will die) martyr". (Related by al-Bukhari).

${ }^{26}$ Abū Muḥammad Maḥmūd ibn Aḥmad ibn Mūsā ibn Aḥmad ibn Husain al-Ghītābī alḤanafî Badr al-Dīn al-'Ainī, 'Umdah al-Qārī' Syarḥ Șậịh al-Bukhārī, vol XIV (Bairūt: Dār Ihyā' alTurāंs al-'Arabī, n.d.), p. 117.

${ }^{27}$ Departemen Agama RI., Pelestarian Lingkungan Hidup (Jakarta: Lajnah Pentashihan Mushaf al-Qur'an, 1431 H./2010 M.), p. 272-273.

${ }^{28}$ Muhammad ibn Ismā’ìl Abū 'Abdillāh al-Bukhārì al-Ju’fí, Saḥịh al-Bukhārī, vol V, p. 15. 
The above hadith describes the incident of the earthquake when the Prophet saw. It was climbing mountain Uhud with some companions. To the researcher's opinion, the term فَرَجَ whe which means "earthquake or shock occurs" does not contain metaphorical or figurative meaning. The word must be understood textually because, in reality, the Prophet saw. with the companions really felt Mount ain Uhud vibrating at that moment. This textual interpretation is corroborated by other hadiths with the same form of events when the Prophet climbed the mountain Sabir. In this account,

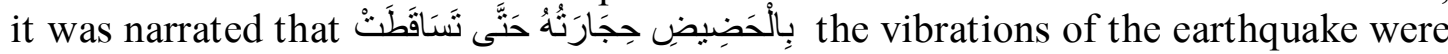
so hard that the rocks on Mount Sabir were falling off. ${ }^{29}$ A point that might provoke different views from the above hadith lies in the chronology of Mount Uhud's trembling and the meaning of the pause when the Prophet saw. say أحُدُ اسنُُنْ. This point can invite different opinions.

'Abd al-Muhsin ibn Ḥamid in his book Syarh Sunan Abī Dāwud, explains that the pause on the shaking of the mountain when the Prophet saw. said form of the privilege of the Prophet saw. and the virtues of the accompanying friends. ${ }^{30} \mathrm{~A}$ different view on the subject holds that the mountain vibrated to welcome the arrival of a Prophet of Allah the Almighty together with the people of siddiq and syähid. As for the pause on the mountain's trembling, it was because of their primacy in front of Allah Almighty. But to the researcher's opinion, the second view of the mountain's vibrating out of respect is lacking the sound basis of argumentations. And the Prophet's call for the mountain to calm down or to stop vibrating indicated his noble virtue, which the researcher refers to as the miracle of the Prophet. It was one of the many miracles he had that are called hissiyah.

There is another hadith which tells about the story of the Prophet saw. were together with the companions climbing a mountain when an earthquake struck them, namely when the Prophet saw. was on the Mountain Sabir and Hira'. ${ }^{31}$

In the researcher's opinion, these traditions show the virtue and privilege of the Prophet saw. with his companions. They were people who were granted protection from Allah the Almighty because of their dhikr (remembrance of God) at all times and all conditions. This led them to obtain high virtues..$^{32}$ Thus, in the view of the researcher these prophetic traditions were proof of one of the Prophet's miracles, which is hissiyah. As for other hadiths that explain the view of the Prophet

See; 'Ali ibn Sulțān Muhammad Abū al-Ḥasan Nūr al-Dīn al-Malā' al-Harawì al-Qārì, Mirqāh al-Mafātịh Syarḥ Misykāh al-Maṣābīḥ, vol IX (Bairūt-Libanōn: Dār al-Fikr, 1422 p./2002 M.), p. 3923.

${ }^{30}$ Abd al-Muhsin ibn Hamid ibn 'Abd al-Muḥsin ibn 'Abdillāh ibn Ḥamid ibn al-'Abbād alBadr, Syarh Sunan Abī Dāwud, vol XIII (Bairūt: Dār al-Kutub al-'Ilmiyah, 1415 H.), p. 520.

${ }^{31}$ Muhammad ibn 'Isā ibn Sūrah ibn Mūsa ibn Ḍaḥāa al-Tirmiži Abū 'Isāa, Sunan al-Tirmiżī, Juz VI III (Cet. II; Mesir: Syirkah Maktabah wa Maṭba'ah Muștafā al-Bābī al-Ḥalabī, 1395 H./1975 M.), p. 68. See also juga; Muslim ibn al-Ḥajjāj Abū al-Ḥasan al-Qusyairì al-Naisābūīi, Saḥịh Muslim, vol IV, p. 1880.

${ }^{32}$ Ibn Bațạā Abū al-Ḥasan 'ATi ibn Khalf ibn 'Abd al-Mālik, Syarh Saḥịh al-Bukhārì li ibn Battāl, vol X (al-Su'ūdiyah al-Riyāḍ: Maktabah al-Rusyd, 1423 H./2003 M.), p. 32. 
saw. about the earthquake that will occur in the fut ure is in his capacity as the bearer of risālah.

3. Earthquakes in the fut ure according to the prophecy of the Prophet

There is a piece of information in the hadith of the Prophet saw. about the occurrence of a shock in the future, as in the hadith related by al-Bukhäri.

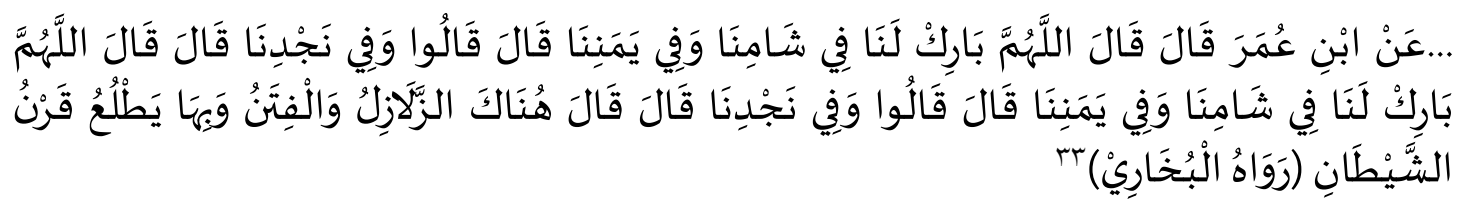

Translation:

...from Ibn 'Umar, he sai, , He prayed: "O Allah, bless us in our country Sham and our country, Yemen." Ibn "Umar said, The Companions said, "Also for our country Najed." He prayed again: "O Allah, bless us in our country Sham and our country Yemen." The Companions said again, "Also for our country Najed." Ibn 'Umar said, He then said: "There will be a disaster and devastation, and a demonic horn will appear there." (Related by al-Bukhāri).

The information about the earthquake in the prediction of the Prophet saw. above is of metaphysical issues. It is an unknown, unreal or hidden occasion. There are so many things that humans may not know in this life, for example when is the exact time of the doomsday or when will death come. Provided with such a situation, it can be seen that the mystery is actually in a multilevel, there is a relative mystery, in the sense that it might be hidden for some but not for others. Or else, it might be a mystery at a certain time but not ar another time. For example, in the past people knew, but now that time has passed, it is no longer known, or vice versa, people did not know it in the past, but now it is known, so that it is no longer mystery. There is also an absolute mystery that is unknown to human beings on their lives on earth, or they will never be able to know, namely the essence of Allah the Almighty. ${ }^{34}$

The prophecy presented by the hadith of the Prophet saw. above is an event that is believed to be happening either in the near or in the long term. The problem that arises lies in the interpretations to reveal the true meaning, whether textual or contextual. Textually the hadith mentions the primacy of the city of Mecca and Medina, as the Prophet saw. set the miqat for the people of Sham in al-Juhfah, for the inhabitants of Medina at $z u$ al-Hulaifah and for the inhabitants of Najed in Qarnun, thus the chronology of the prayer of the Prophet saw. over these areas. ${ }^{35}$

In the opinion of the researcher, the wording of the hadith is still ambiguous that it is necessary to apply contextual interpretations of the content. This hadith has two problems to be solved, namely the time of the occurrence of an earthquake and the meaning of the state of Najed. Is it in the real meaning or in a figurative connotation?. The reason is that there are differences among the scholars in

\footnotetext{
${ }^{33}$ Muhammad ibn Ismā’ìl Abū 'Abdillāh al-Bukhārì al-Ju’fí, Saḥịh al-Bukhārī, vol II, p. 33.

${ }^{34}$ M. Quraish Shihab, Mukjizat al-Qur'an (Bandung: Mizan, 1998 M.), p. 193.

${ }^{35}$ See; Muḥammad ibn Ismā'ìl Abū ‘Abdillāh al-Bukhārì al-Ju'fí, Saḥị̣ al-Bukhārì, Vol II, p.
} 133. 
explaining the Najed country itself. Some say Najed is from the east, al-Kat ta bi say Najed is from the east side, ${ }^{36}$ and another opinion says that what is actually meant is Iraq. ${ }^{37}$ To the researcher's analysis, the above hadith shows prophetic knowledge that explains the capacity of the Prophet saw. as an apostle of Allah the Almighty. The time and place of occurrence of the event in the view of the researcher is an unseen subject matter that has no definite information. Rather, they imply different interpretations, as it might be that the area in question is any country in the eastern hemisphere of Najed. Thus this information as a revelation that contains the views of the Prophet saw. which surely will happen in the future.

4. Earthquakes as a punishment for Muslims in this world life

The word $a z a b$ or punishment is not only used for torment and punishment in the hereafter, but it is also used for torment and punishment in this world. ${ }^{38}$ The Prophet's hadith also explains in a more specific orientation about the punishment of the world to Muslims, as in the account of Abū Dāwud.

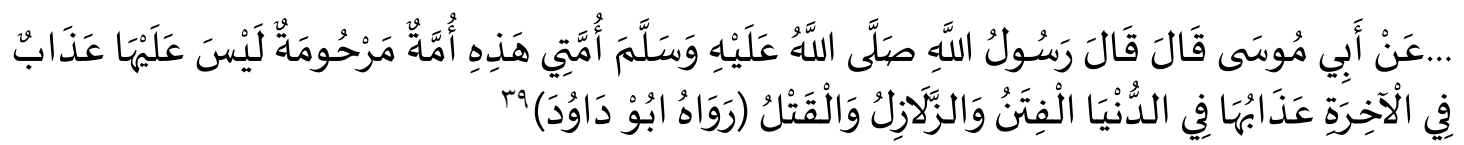

Translation:

...from Abū Mūsa, he said, The Messenger of Allah said: "My people are honorable people, in the hereafter they will not get torment, their punishment is in the world; namely with the existence of disparage, earthquakes and warfare." (Related by Abū Dāwud).

The above hadith is absolute and general in nature, and it is intended for all Muslims who are obedient and following the teachings of Islam. In fact, there are quite many of the Muslims who also commit sins, and hence they are not the group of people referred to in the above hadith as being blessed with God's love. Those who commit sins will still get punishment in proportion to their actions, as in the word of God Almighty in Surat al-Isrā'/ 17: 15.

${ }^{36} \mathrm{Abū}$ Muḥammad Mạ̣mūd ibn Aḥmad ibn Mūsā ibn Aḥmad ibn Ḥusain al-Ghìtābi alḤanafî Badr al-Dīn al-'Aini, 'Umdah al-Qārī' Syarh Saḥịh al-Bukhārī, vol XXIV, p. 200.

${ }^{37}$ Abd al-Muḥsin ibn Aḥmad ibn 'Abd al-Muḥsin ibn 'Abdillāh ibn Ḥamid al-'Abbād al-Badr, Syarh al-Arba'in al-Nawawiyah, vol III, p. 10.

${ }^{38}$ See further; Abdul Rahman Rusli Tanjung, "Studi terhadap Kata-kata yang Semakna dengan Musibah dalam al-Qur'an", Jurnal Analytica Islmaica 2, no. 3 (2001): p. 264. See; Muhammad ibn Aḥmad al-Anșārì al-Qurțubī, al-Jāmi' li Aḥkām al-Qur'ān, vol VII (Khairo: Dār al-Kutub al'Arabiyah, 1378 H./1967 M.), p. 167. See also; Al-Rāghib al-Aṣfahānī, Mu'jam Mufahras Alfäz alQur'ān (Bairūt: Dār al-Fikr, t.th.), h. 339. Lihat lagi; Muhammad Rasyīd ibn 'Ali Rị̣ā ibn Muhammad Syams al-Dīn ibn Muhammad Bahā' al-Dīn ibn Manlā'Khalifah al-Qulamūnì al-Ḥusainì, Tafsìr alQur'ān al-Hakīm (Tafsìir al-Manār), vol I (Khairo: Dār al-Manār, 1967 M.), p. 147.

${ }^{39} \mathrm{Abū}$ Dāwud Sulaimān ibn al-Asy'aś ibn Isḥāq ibn Basyīr ibn Syaddād ibn 'Amrū al-Azadi al-Sijistānī, Sunan Abī Dāwud, vol IV, p. 105. 
The wording in the hadith above clearly mentions that Muslims will not go through punishment in the Hereafter, as punishment for them is given during their lives in this world in the form of slander, earthquake, and war. There is a mention of in the hadith, which, according to the scholars is intended in figurative meaning. It does not convey real meaning. The word al-zala zil is an expression of majaz which means violence and terror experienced by Muslims during their lives in this world. ${ }^{40}$ In this context, the suffering experienced by Muslims in this world in the forms of slander, terror, and oppression in parts of the test intended for the believers, while those who disbelieve it can mean punishment that indicates that they do not belong to the loved ones. The suffering of the believers is the penalty to the mistakes they have made in the world, as in the hadith related by al-Bukhäri, wherein the Prophet saw. said: "A Muslim is never afflicted with a disease and fatigue, anxiety and grief, nor annoyance and distress, and not even a thorn that hurts him except that Allah will erase his faults." 41

In the researcher's view, the term earthquake in the above hadith is a majaz, more as a figure of speech, that indicates chaos, oppression, suffering and all forms of unfairness befalling Muslims. There is a correlation between the phrase "the people who are loved" and the phrase "the punishment in the world in the form of earthquakes." They basically mean that the believers who are afflicted with suffering will receive abolition for some parts of their faults and mistakes that they belong to the group of people who are blessed with grace and love of Allah the Almighty.

5. Earthquakes are signs for the of Muslim prosperity

One of the Prophet's hadith explains that earthquakes are signs of the end of Muslim prosperity, as in the hadith related by Ahmad:

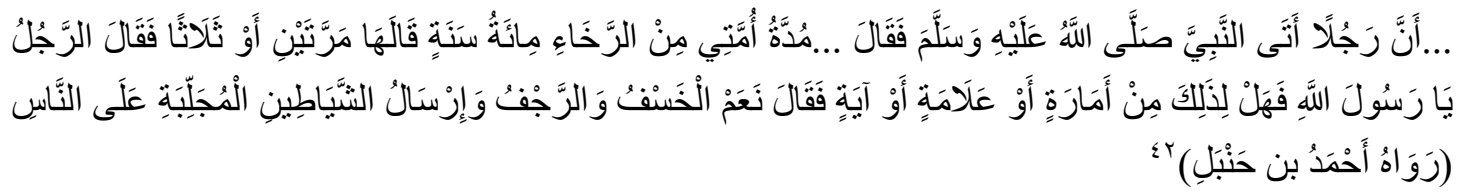

Translation:

...that someone came to the presence of the Prophet p.b.u.h. then said: "... the duration of the prosperity of my people is one hundred years." The Messenger of Allah said it two or three times then the person asked: "O Messenger of Allah! Are there any signs?" The Messenger of Allah said:"Yes: lunar eclipses, earthquakes, and Satan is sent to tempt human beings." (Hadith related by Ahmad).

${ }^{40}$ Zain al-Dīn Muhammad al-Mad'ù Ba'bad al-Ra'ūf ibn Tāj al-'Ārifīn ibn 'Ali ibn Zain al'Ābidin al-Haddāđi, al-Taisīr bi Syarh al-Jāmi' al-Saghīr, vol I (al-Riyāḍ: Maktabah al-Imām alSyāfi'i, 1408 H./1998 M.), p. 237.

${ }^{41}$ Muḥammad ibn Ismā'ì Abū 'Abdillāh al-Bukhārì al-Ju’fi, Saḥịh al-Bukhāri, vol VII, p. 114.

${ }^{42}$ Abū 'Abdillāh Aḥmad ibn Muḥammad ibn Ḥanbal ibn Hilāl ibn Asad al-Syaibānì, Musnad Aḥmad ibn Hanbal, vol XXXVII (Muassasah al-Risālah, 1421 H./ 2001 M.), p. 431. 
The above hadith explains that the events of the earthquakes and lunar eclipses are signs for the end of prosperity of the Prophet's people. When the hadith is understood textually, all the signs that indicate the end of Muslims' prosperity has occurred; they were even experienced by the Prophet himself. ${ }^{43}$ So, to the researcher's viewpoint, the abovementioned hadith should be understood contextually, especially because the construction of the hadith is in the form of conversation. Someone came and asked the Prophet p.b.u.h. about the length of the prosperity of the Muslims, then the Prophet answered "one hundred years".

To the researcher's analysis, the phrase "سنَّةٍ مِائَة "the prosperity of Muslims is only one hundred years," comprises figurative meanings. The number that points to a hundred years is not in the sense of quantity. The number of years mentioned simply indicates a very long span of time. A simpler study can be explained that the prosperity of Muslims is limited by the occurrence of various kinds of natural disasters that damage the order of life of religious communities. Furthermore, the signs mentioned by the Prophet such as earthquakes and eclipses as are common incidence in his era. The terms earthquakes and eclipses mentioned in the hadith above are therefore should comprise some figurative functions to mean shock, chaos, oppression and all kinds of anxiety and sadness that afflicts Muslims. This way of looking at the subject matter is closer to the signs of the end of the Muslims' prosperity, as in the hadith related by Abū Dāwud.

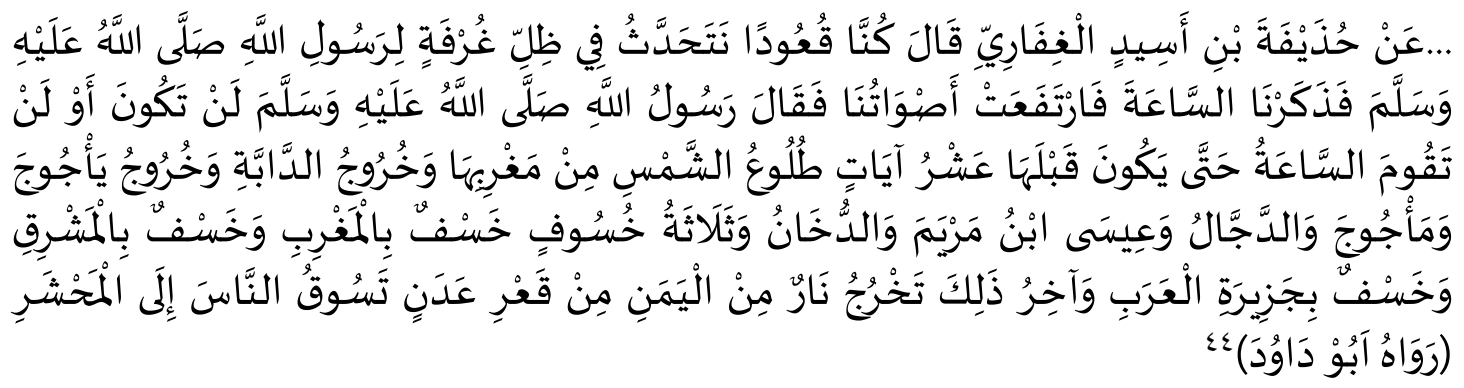

Translation:

...from Huzaifah ibn Asid al-Ghifari, he said: "We were sitting together beside the Prophet's room while talking about the Day of Judgment, our voices were so loud that the Messenger of Allah said: "It will not happen, or no doomsday will come until ten signs appear; the rising of the sun from west, the emergence of crawling animals, the appearance of Ya'uj and Ma'juj, Dajjal, Isa the son of Mary, smoke and three earthquakes (landslides), landslides in the West, East and in the Arabian Peninsula. And the last sign is the release of fire from Yemen, from the bottom of the ground "And, and the fire will drive people to the field of Mahsyar." (Hadith related by Abu Dawud).

${ }^{43}$ The Prophet explained in one of his hadith that the sun and the moon will not have an eclipse due to the passing away of a human. Rasther, the two are signs of the Majesty of God. See Muḥammad ibn Ismā'ìl Abū 'Abdillāh al-Bukhārì al-Ju'fí, Saḥị̣ al-Bukhārī, vol II, p. 34. See also Muḥammad ibn Ismā'ìl Abū ‘Abdillāh al-Bukhāri al-Ju’fí, Sahịị̣ al-Bukhārī, vol IV, p. 22.

${ }^{44}$ Abū Dāwud Sulaimān ibn al-Asy'aś ibn Isḥāq ibn Basyīr ibn Syaddād ibn 'Amrū al-Azadi al-Sijistāni, Sunan Abī Dāwud, vol IV, p. 114. 
The explanation provided in the hadith above regarding the signs for the end of the Ummah's life or the coming of the Day of Judgment mentions about an occurrence of massive damages and destructions. This provides more strong grounds to confirm the contextual meaning that the term earthquake mentioned in the above hadith comprise figurative meanings, which is interpreted as massive chaos.

5. Earthquakes to answer the prayers of the saintly servant

Prayer is the momentum of a servant's closeness with his Lord, both in good time and hard time. There is a story in a hadith that explains about the prayer of a young man who was helped by Allah the Almighty with an earthquake. The hadith was narrated in the Sahih Muslim.

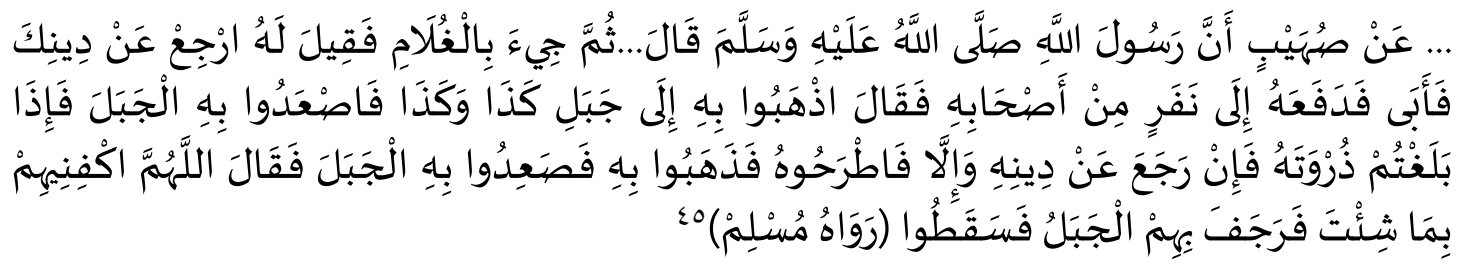

Translation:

...from Suhaib that The Prophet p.b.u.h. said: “... After that, the young man was brought in and the king said to him: Leave your religion! The young man refused to obey. Then the king handed him over to a group of his soldiers, the king said: 'Take him to this and this mountain, bring him up if he wants to leave his religion leave him alone but if he does not, throw him from the top of the mountain. They took him to the top of the mountain and the young man prayed: O God, just keep me from them as you wish. It turned out that the mountain shook them and they all fell down..." (Hadith related by Muslim).

The above hadith puts on view the help of Allah the Almighty to the servant who always drew near and was always submissive and resigned everything to Allah. ${ }^{46}$ The researcher sees that the above hadith carries literal meaning, as the textual interpretation explains the occurrence of the earthquake with the vibrations of the surface of the mountain. This is indicated by the phrase فَسَقَطُو الْجَبَلُ بِهِْْ فَرَجَفْ "the mountain experienced an earthquake, then they all fell down (except the young man)." 47 Thus in the view of the researcher, this hadith serves as evidence of the power of Allah the Almighty as well as a form of help to His devoted servant.

6. Earthquakes as a result of moral decadence

Deterioration on the social barometer is marked by deterioration of human's theological faith and morality. Theological faith indicates the relationship with Allah the Almighty, whereas morality generally indicates relationships with fellow humans. If these two devices are deteriorated, the life of humanity will accordingly

${ }^{45}$ Muslim ibn al-Ḥajjāj Abū al-Ḥasan al-Qusyairī al-Naisābūrī, Saḥịh Muslim, vo IV, p. 2299.

${ }^{46}$ Muhammad 'Ali ibn Muḥammad ibn Ghilān ibn Ibrāhīm al-Bakrī al-Ṣadiqì al-Syāfi'i, Dalì al-Fāliḥin li Tarīq Riyậ̣ al-Săliḥinn, vol I, (Bairūt-Libanōn: Dār al-Ma'rifah li al-Ṭaba'ah wa al-Nasyr wa al-Tauzi', 1425 H./2004 M.), p. 167.

${ }^{47}$ Muḥammad ibn Ṣāliḥ ibn Muḥammad al-'Usaimīn, Syarḥ Riyāọ al-Ṣāliḥin, vol I (al-Riyāẹ: Dār al-Waṭan li al-Nasyr, 1426 H.), p. 220. 
be destroyed. At that time humans do not have a direction and purpose given that their lives in this world are their solitary objective. In this situation, it is really frightening to read the Prophet's warning as in the hadith related by Ibn Majah.

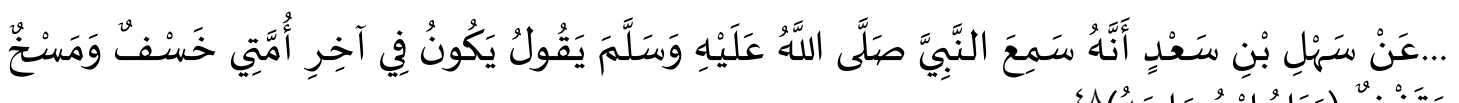

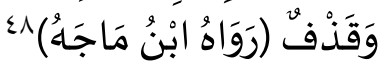

Translation:

...from Sahl ibn Sa'd, that he heard the Prophet p.b.u.h. said: "It will happen at the end of my people a darkening and drowning (to the bowels of the earth), changes in form and slander (allegations of adultery against women)." (Hadith related by Ibn Mäjah).

The hadith above explains that the Prophet's Ummah will go trough a landslide disaster (sinking), and they will be changed on their shape faces to become like animals and they will be attacked with stones from the sky. ${ }^{49}$ Such incidents are intended as warnings as well as a punishment from Allah the Almighty as a result of the destruction of the social order in human life. As in the Prophet's explanation, these incidents were also indicated by the popping of female singers and musical instruments and the widespread of liquor. ${ }^{50}$ The hadith related by al-Tirmizi.

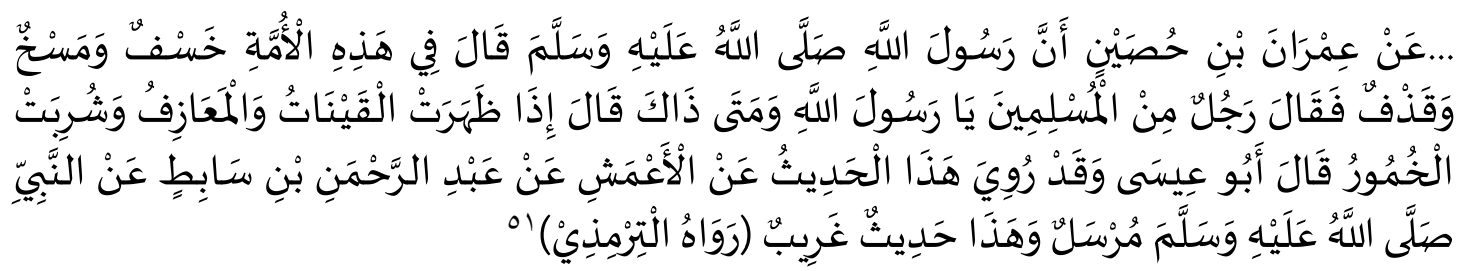

\section{Translation:}

...from 'Imran ibn Husain that the Prophet p.b.u.h. said: "It will happen to this, people landslides, change of appearance, and hurricanes that flung humans," Someone from the Muslims asked: "O Messenger of Allah, when would that happen?" He replied; "When female singers and musical instruments raise and people drink liquor." Abu "Isa said: This hadith is narrated from al-A'masy from' Abd al-Rahman ibn Sabit from the Prophet p.b.u.h.with a missing chain and this hadith is qualified as gharib. (Hadith related by al-Tirmizi).

${ }^{48}$ Ibn Mājah Abū 'Abdillāh Muḥammad ibn Yazìd ibn Qazwīnī, Sunan Ibn Mājah, vol II (Dār al-Kutub al-'Arabiyah, n.d.), p. 1350.

${ }^{49}$ Zain al-Dīn Muḥammad al-Mad'ū Ba'bad al-Ra'ūf ibn Tāj al-'Ārifin ibn 'Ali ibn Zain al'Ābidin al-Ḥaddādi, Faị̣ al-Qadir Syarḥ al-Jāmi' al-Saghïr, vol IV, p. 459.

${ }^{50}$ Zain al-Dīn Muhammad al-Mad'ù Ba'bad al-Ra'ūf ibn Tâj al-'Ārifīn ibn 'Ali ibn Zain al'Ābidin al-Haddādi, al-Taisīr bi Syarh al-Jāmi' al-Saghïr, vol II, p. 179.

${ }^{51}$ Muhammad ibn 'Isā ibn Sūrah ibn Mūsa ibn Ḍaḥhāk al-Tirmiži Abū 'Isāa, Sunan al-Tirmiżī, vol IV, p. 65. 
Another hadith which is judged to be of poor quality by the scholars of hadith is also found in the relation of al-Tirmizi. ${ }^{52}$

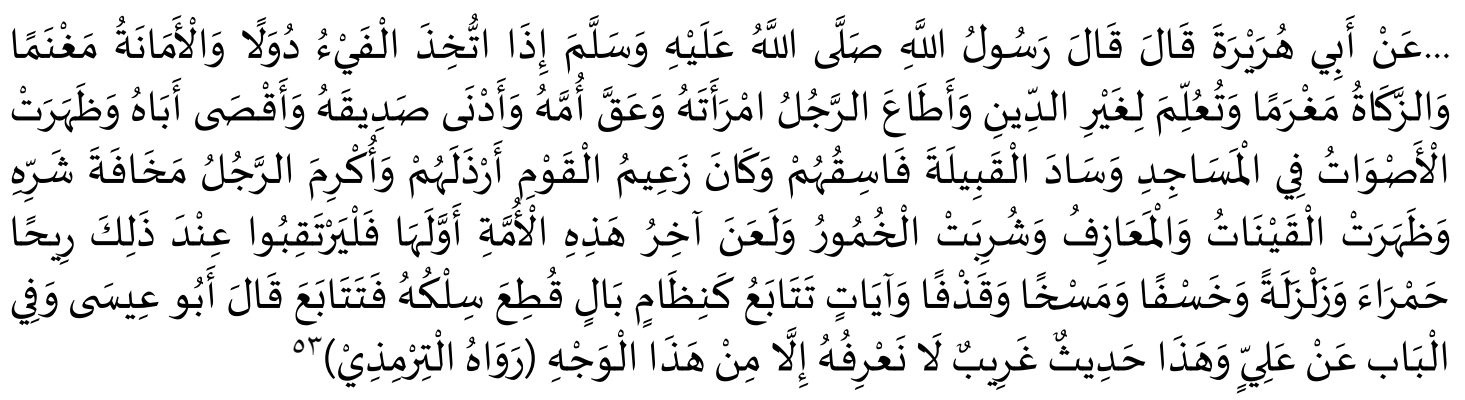

Translation:

...from Abu Hurairah that the Prophet p.b.u.h. said: "When the spoils of war are dominated by certain groups, mandate is used as spoils, almsgiving is used as a fine, people learn except religion, a husband submits to his wife, a son revolts to his mother, a man is intimate with his friend but away from his father, loud voices coming out from mosques, the leader of a tribe is a wicked person among them, the leader of a people is the most disgraceful person among them, a person is respected out of fear of his crime, the appearance of female singers and musical instruments, drinking liquor, and the last person of this people curses the predecessors, then wait for that moment where there will be a red wind, earthquake, landslide, change of appearance, throws, and signs of doomsday that follow one after another like an old arrangement of jewelry that is cut off and is let loose one after another." Abu 'Isa said, in this case, there is a similar hadith from "Ali and this is a gharib hadith. We do not know it except through this line of transmission. (Hadith related by al-Tirmizi).

The above hadiths explain some forms of social damage occurring in human life. Ibn al-Jauzi argued that this event would take place took place in an area where the population is immoral, as people have been deceived by the enemies of Allah the Almighty. They are in common practice of actions and behavior clearly prohibited by religion. They are not aware that in fact, they are only deceiving themselves in the form of knowledge, reason and religion, and their hearts that are ignorant and erroneous. $^{54}$

${ }^{52}$ This hadith is considered weak by al-Suyūṭi dan al-Albānī. See; 'Abd al-Raḥmān ibn Abī Bakr Jalāl al-Dīn al-Suyūtịi, Sahịh wa Däif al-Jāmi' al-Sagīir wa Ziyādah. No1300. See further; Abū 'Abd al-Raḥmān Muhammad Naṣr al-Dīn ibn al-Hajjāj Nūh ibn Najāti ibn Ādam al-Asyqūduri al-

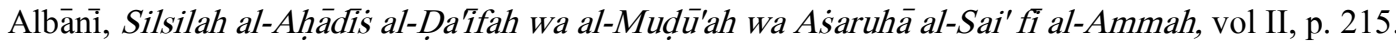

${ }^{53}$ Muḥammad ibn 'Isā ibn Sūrah ibn Mūsa ibn Ḍaḥhāk al-Tirmiżi Abū 'Isāa, Sunan al-Tirmiżī, vol IV, p. 65 .

${ }^{54}$ Muhammad Asyraf ibn 'Umair ibn 'Ali ibn Haidar Abū 'Abd al-Rahmān Syarf al-Haq, 'Aun al-Ma'būd Syarh Sunan Abī Dāwud, vol XIII, p. 185. See also; Abū al-Hasan 'Ubaidillāh ibn Muhammad ibn 'Abd al-Salām ibn Khān Muhammad Amānullāh ibn Hisān al-Dīn al-Rahmānī Mubārakfūri, Mar'äf al-Mafătị̆ Syarh Misykāh al-Mașābīh, vol I, p. 204. Compare to; 'Ali ibn Sulțān Muhammad Abū al-Ḥasan Nūr al-Dīn al-Malā' al-Harawì al-Qārì, Mirqāh al-Mafätīh Syarh Misykāh al-Mașābīh, vol I, p. 190. 
To the researcher's regard, the terms earthquakes or sinking in this context are meant for their literal meanings, that is, in the form of earthquakes (shocks) on the surface of the earth. Explanation of this part of the earthquake as the law of causality against the destruction of the order of life. Such events are explained in both the Qur'an and al-Hadith, such as the story of the prophet Lut a.s. and other prophets. However, it provokes a longer discourse to make sense about the law of causality between the destruction of the barometer of life with the befalling of punishment in the form of an earthquake. Furthermore, as a matter of fact, such incidents take place in many life processes. Hence the scheme of cause and effect in this context does not apply immediately with any occurrence of immoral behavior. The point of reference that should be held is that when a warning about the truth from God has come while people keep ignoring and keep engaged in disbelieving.

7. Geographical areas with high risks of encountering earthquakes

Earthquake disasters cannot be predicted, but the impact can be reduced through disaster mitigation efforts. A residential area adjacent to the source of an earthquake is a very vulnerable area. ${ }^{55}$ Thus efforts need to be made in the forms of strategic steps to reduce or minimize the impact or damage and to minimize loss of property or fatalities ${ }^{56}$

The researcher views that the phenomenon of natural disasters such as earthquakes can generally be classified into two types, namely natural and nonnatural (with human intervention) disasters. The first category refers to disasters that occur because of God's determination that humans have no power to reject or cancel. The second category is a disaster that results from humans' own actions. By classifying the source of the disaster in this way, it is no longer perceived only as a provision that must be accepted as it is. Humans play a big role in replacing one destiny with another destiny of God, depending on how much they are willing to make efforts. ${ }^{57}$

The Prophet p.b.u.h. provides information in a hadith about areas that are at high risk of natural disasters, including earthquakes. This hadith can serve as a ground argument for the point that humans have the power to reject or to be trapped in an earthquake, as in the hadith related by Abū Dāwud.

${ }^{55}$ Badan Koordinasi Nasional Penanggulangan Bencana, Pengenalan Karakteristik Bencana dan Upaya Mitigasinya di Indonesia, ed. Triutomo, et all. (Jakarta: Direktorat Mitigasi Lakhar Bakornas PB, 2007 M.).

${ }^{56}$ Badan Nasional Penanggulangan Bencana (BNPB), Indeks Rawan Bencana Indonesia, 2011.

${ }^{57}$ Munawir, "Fenomena Bencana dalam Al-Qur'an: Perspektif Pergeseran teologi dari Teosentris ke Antrosentris", Jurnal Maghza I, no. 2 (2016): p. 81. See for more details; M. Quraish Shihab, Wawasan al-Qur'an Tafsir Tematik atas Pelbagai Persoalan Umat, Edisi Ke-2 (Bandung: Mizan, 1435 H./2014 M.), p. 78. 


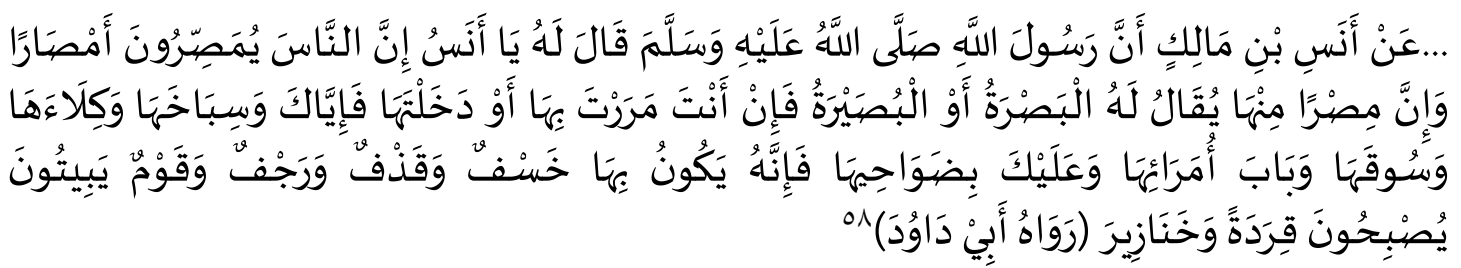

Translation:

...from Anas ibn Malik that the Messenger of Allah pb.u.h. once said to him: "O Anas, actually human beings will occupy many places, and one of those places is called Basrah, or Busairah. If you pass by that place or enter into it, then avoid places where the soil is salty (spacious because there are only a few trees), and anchoring places (docks), markets and their rulers. Go to remote places (mountainous areas), because in these areas there are a lot of sinking (to the bottom of the ground), hurricanes and earthquakes. There you will also meet,people who spend the night and in the morning they turn into apes and pigs." (Hadith related by Abū Dà wud).

The above hadith explains that there are four areas classified to be at high risk of having natural disasters or earthquakes. These comprise places where the soil is salty, dockyards, markets, and rulers' places. There is an explanation from the scholars concerning these places. Salty lands are said to be at risk of disasters because they lack trees, the dockyards have the same potential because of the frequent heavy winds from the sea, whereas the markets and the rulers are equally in danger because they are related to tyranny and corruption. ${ }^{59}$

To the researcher's view, the abovementioned places said to be at risk of earthquakes can be classified into two categories. First, the earthquake areas have seen from the geological activity or the geographic areas such as the salty land and the dockyards. Secondly, the areas that can provoke natural disasters because of the social or individual activities that have gone astray. These areas comprise markets, wherein cheating makes a common practice and the places of the corrupt rulers.

8. The end of time earthquake in Medina

Medina is the city of the Prophet Muhammad p.b.u.h. A safe, peaceful and prosperous country, a place of refuge for believers and the meeting place of the Muhajirin and Ansār. The city of Medina is full of blessings and has been glorified and praised as the best place after Mecca. ${ }^{60}$ There are so many references that explain the virtues, the holiness and the position of this city. These are visible in the forms of news or encouragement, motivation and even threats to those who have a

${ }^{58} \mathrm{Abū}$ Dāwud Sulaimān ibn al-Asy'aś ibn Isḥāq ibn Basyīr ibn Syaddād ibn 'Amrū al-Azadi al-Sijistānì, Sunan Abī Dāwud, vol IV, p. 113.

${ }^{59}$ 'Abd al-Muḥsin ibn Hamid ibn 'Abd al-Muhsin ibn 'Abdillāh ibn Ḥamid al-'Abbād al-Badr, Syarḥ Sunan Abī Dāwud, Juz XV, p. 484. Lihat juga; 'Ali ibn Sulțān Muhammad Abū al-Hasan Nūr

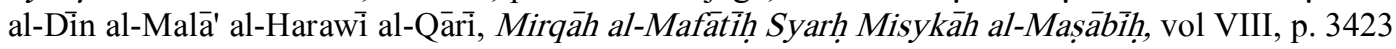

${ }^{60}$ Syaikh Amīn ibn 'Abdillāh al-Syaqawī, Faḍāil al-Madinah wa Haramātihā, terj. Abu Umamah Arif Hidayatullah, Keutamaan Madinah (Islamhouse, 1435 h./2013 M.), p. 3. 
negative intention for the city. ${ }^{61}$ The Prophet himself prayed for the prosperity of the city of Medina, as he said in the hadith related by Muslim.

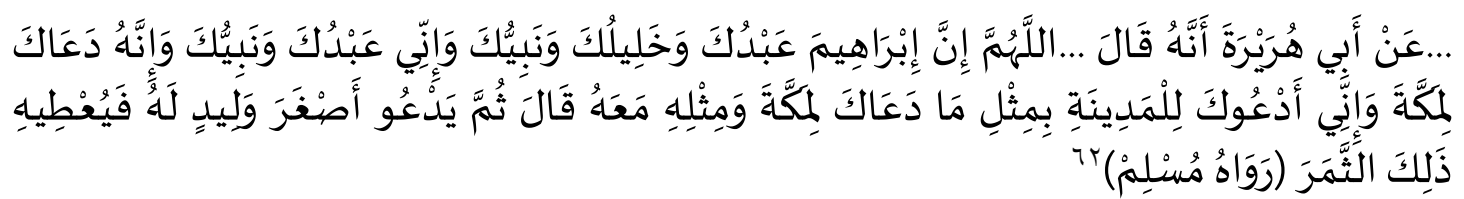

Translation:

...from Abu Hurairah that the Prophet p.b.u.h. said: "O God, bless our fruits, bless our city, bless our Sa', and bless our Mud. O God, the prophet Abraham is your servant and your lover, whereas I am Your servant and Your prophet He prayed to You for the prosperity of Mecca, and I pray to You for the prosperity of Medina, just as Abraham prayed for the city of Mecca." Abu Hurairah said, then he called a boy and gave the fruit to him. (Hadith related by Muslim)

The above hadith explains about the prayer of the Prophet p.b.u.h. for the prosperity of the city of Medina. The city is extended with all conveniences for the entire population. It is a city wherein prayers are promised to be granted. Medina is the city that has the virtue and blessing of the world, the Hereafter, and the hissiyah. ${ }^{63}$ Many reliable narrations explain about the primacy of the city of Medina, which is tightly guarded by angels at each gate of from the evil of Dajjal ${ }^{64}$ To the researcher's opinion, the guarding of the city of Medina from the evil of Dajjal is an event that will occur at the end of time because Dajjal himself will descend when the world is approaching the end. Abū al-Ma'ani argued that on the road to the gate of Medina there was a mountain that Dajjal could not pass through. ${ }^{65}$ Hence, in this context, one form of God's guarding the city of Medina through his angels from the evil of Dajjal is by رَجَفٍْ ثَََلَّ, three shocks in Medina. This is as in the hadith related by al-Bukhari.

${ }^{61}$ Abd al-Muḥsin ibn Aḥmad ibn 'Abd al-Muḥsin ibn 'Abdillāh ibn Aḥmad ibn Hamid al'Abbād al-Badr, Fạ̣l al-Madīnah wa Adāb Sakinahā wa Ziyārahā (Maṭba'ah al-Narjiz, 1421 H./2000 M.), p. 4-9.

${ }^{62}$ Muslim ibn al-Ḥajjāj Abū al-Ḥasan al-Qusyairī al-Naisābūrì, Șạ̣ị̣ Muslim, vol II, p. 1000.

${ }^{63 \prime}$ Ali ibn Sulțān Muḥammad Abū al-Ḥasan Nūr al-Dīn al-Malā' al-Harawī al-Qārì, Mirqāh alMafătịh Syarḥ Misykāh al-Mașābịh, vol V, h. 1874. Ada pula yang mengatakan doa Nabi saw. untuk kebarkahan Madinah bermakna taibah. See; Muḥammad ibn 'Abd al-Bāqī' ibn Yūsuf al-Zarqānī alMișrīi al-Azharī, Syarḥ al-Zarqānī 'alā Muwatța' al-Imām Mālik, vol IV (al-Qāhirah: Maktabah alSaqāfah al-Dīniyah, 1424 H./2003 M.), p. 344.

${ }^{64}$ Muḥammad ibn Ismā’ìl Abū 'Abdillāh al-Bukhārì al-Ju’fí, Saḥịh al-Bukhārī, vol III, p. 22.

${ }^{65} \mathrm{Abū}$ Muḥammad Mạ̣mūd ibn Aḥmad ibn Mūsā ibn Aḥmad ibn Ḥusain al-Ghītābì al-

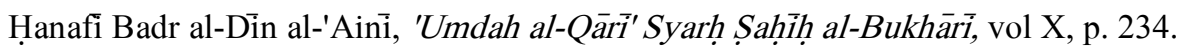




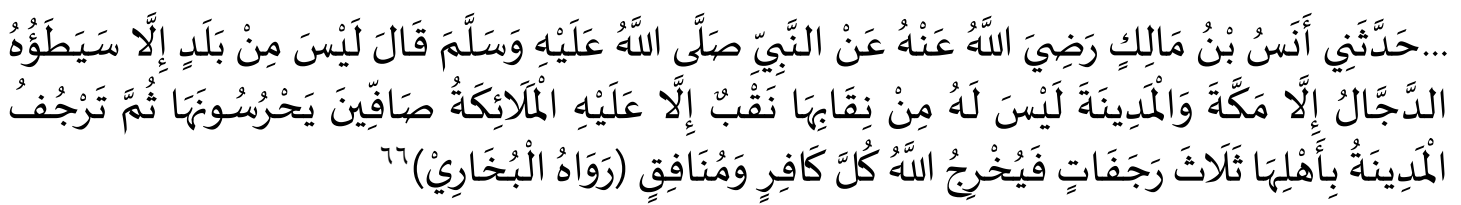

Translation:

...told us, Anas ibn Mālik ra. narrated to me from the Prophet p.bu.h. He said: "There is no country that Dajjal will not enter except Makkah and Medina, because there is no entrance from the gates except the angels marching to guard it. Then Medina will shake three times so that Allah will send unbelievers and hypocrites out." (Hadith related by al-Bukhari).

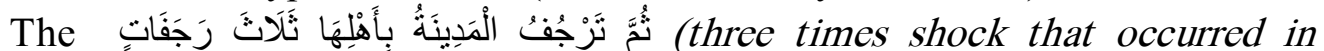
Medina) in the above hadith will drive out unbelievers and hypocrites from within the city of Medina ${ }^{67}$ The researcher tends to see that the meaning of the term (shock) in the hadith above does not contain absolute meaning as a form of the earthquake on the surface of the earth. The occurrence of earthquakes in the historical fact of humanity has destroyed either believer, infidels or hypocrites. If the wordings of the hadith must be understood in a literal meaning, it is very difficult to accept the situation and conditions based on human common sense. Furthermore, in the view of the researcher, the hadith presented as the object of study does not speak of earthquakes or physical shocks. Rather, the shock meant was a non-physical one so as to be able to expel infidels and hypocrites existing in Medina. ${ }^{68}$ This is as in the word of Allah the Almighty in Surah al-Baqarah/2: 214.

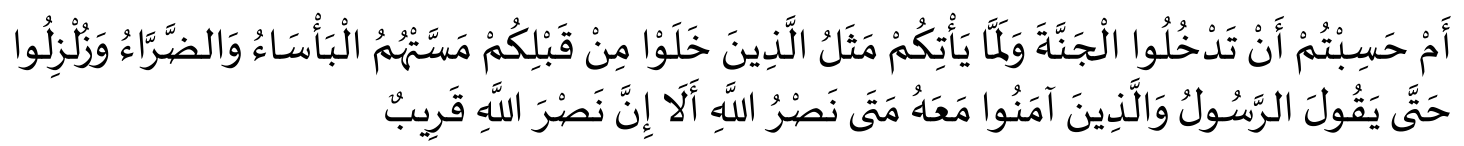

Translation:

Or do ye think that ye shall enter the garden (of bliss) without such (trials) as came to those who passed away before you? They encountered suffering and adversity, and were so shaken in spirit that even the Messenger and those of faith who were with him cried: "When (will come) the help of Allah."Ah! verily the help of Allah is (always) near!

Shakings in a non-physical meaning is also found in the Prophet's hadith, as related by al-Bukhāri with the position of hadith mauqüf. ${ }^{69}$

${ }^{66}$ Muḥammad ibn Ismā’ìl Abū ‘Abdillāh al-Bukhārī al-Ju’fí, Saḥịh al-Bukhārī, vol III, p. 22.

${ }^{67 ، A}$ Ali ibn Sulțān Muḥammad Abū al-Ḥasan Nūr al-Dīn al-Malā' al-Harawī al-Qārì, Mirqāh al-Mafätīh Syarḥ Misykāh al-Mașäbịh, vol V, p. 1882.

${ }^{68}$ See; Abū Muhammad Maḥmūd ibn Aḥmad ibn Mūsā ibn Aḥmad ibn Ḥusain al-Ghìtābì alHanafî Badr al-Dīn al-'Ainī, 'Umdah al-Qārī' Syarh Saḥị̣ al-Bukhārī, vol XXIV, p. 216.

${ }^{69}$ Mauqūf hadith is words, deeds or traits that are based on.companion. Lihat; 'Abdullāh ibn Yūsuf al-Jadi', Tahrīr 'Ulūm al-Hadìis, Juz I (Cet. I; Bairūt: Muassasah al-Rayyān li al-Ṭaba'ah wa alNasyr, 1424 H./2003 M.), h. 39. 


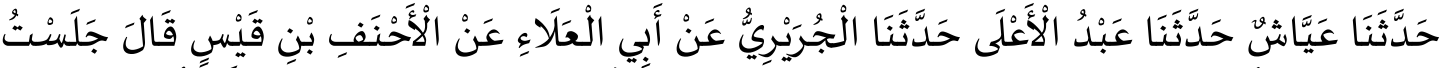

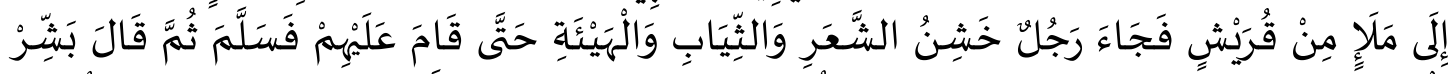

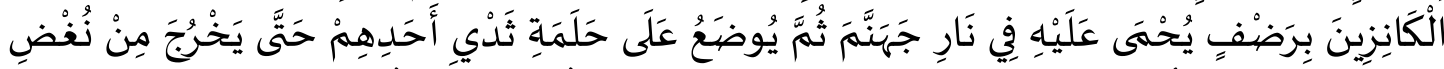

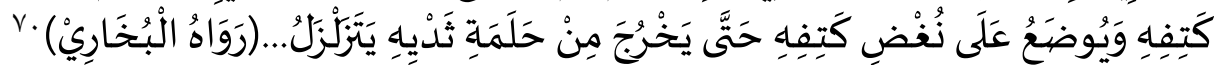

Translation:

'Ayyä̀d narrated to us, Abd al-A'lā narrated to us, al-Jurairī narrated to us from Abu al-'Ala from al-Âhnaf ibn Qais, he said: I was sitting with the authorities of the Quraysh, then came a person whose clothes and hair were in a mess and he stood among them, said his greetings and said, "Give good news to those who store their possessions with stones that are strangled at him in Hell then it is placed in the breast area until it comes out of the tip of his shoulder bone, then it is placed on the tip of his shoulder bone until it comes out on the breast area until it shakes (Hadith related by Al-Bukhāii).

The word zalzalah in the verses and hadith above contains figurative meanings, not in the sense of shocks that occur on the surface of the earth. ${ }^{71}$ Such is also the case of the term "shock" in the hadith which is the subject matter of the current study. The intensity of the non-physical shock (in the form of the shock of the soul, panic or doom) suffered by the infidels and the wicked force them to leave Medina. This view is in line with the hadith related by Muslims wherein the Prophet say:

I was ordered to migrate to a country that would rule other countries. Some hypocrites called it "Yasrib" (although the real name was) Medina. It would remove (the criminals) the way the blacksmith removes iron impurities. (Hadith related by Muslim) $)^{72}$

The above hadith explains that wicked people from the hypocrites and infidels will be removed from the area of Medina. In connection with the previous hadith, the researcher is more likely to use contextual interpretation by interpreting the word jo employ its figurative meaning of "non-physical shock" which expels unbelievers and hypocrites from Medina area.

9. Earthquakes as signs for the coming of the doomsday

The coming of the end of life on earth is of natural mechanism. This happens when the sun is no longer able to control the earth and other planets, either because of an explosion or because the cooling process is very fast. ${ }^{73}$ According to this

${ }^{70}$ Muhammad ibn Ismā'ìl Abū 'Abdillāh al-Bukhārì al-Ju’fi, Ṣạ̣ị̣ al-Bukhārī, vol II, p. 107.

${ }^{71}$ Although some scholars believe that the shocks occurring in Medina means a real earthquak, and this is what makes Dajjal afraid of entering Medina. See Muhammad 'Ali ibn

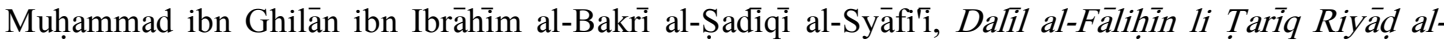
Sălihịin, vol VIII, p. 634.

${ }^{72}$ Muslim ibn al-Ḥajjāj Abū al-Ḥasan al-Qusyairī al-Naisābūrí, Ṣậịh Muslim, vol II, p. 1006.

${ }^{73}$ Ahmad Mahmud Sulaiman, Tuhan dan Sains (Jakarta: PT. Serambi Ilmu Semesta, 2001 M.), p. 52 . 
provision, the earth will meet with a turn of destruction as a continuation of God's words about creation and the Judgment Day. ${ }^{74}$

The doomsday event as reported by the Qur'an and the hadith of the Prophet p.b.u.h. is really terrifying ${ }^{75}$ as terrible shakings take place in the whole universe. ${ }^{76}$ The shocks will destroy the whole nature and they are signs of the end of life in this world. ${ }^{77}$ The shocks that occurred on the Day of Resurrection make people terrified and shocked by the arrival of a very powerful earthquake. ${ }^{78}$ The earthquakes that occur with tremendous strength have never been experienced by humans before, ${ }^{79}$ the shaking forces are so powerful that they throw away material loads contained in the bowels of the earth. This event makes humans lose their foothold as all the surface of the earth experience shocks. ${ }^{80}$

Information that explains the signs of the Day of Judgment can be found in the hadith of the Prophet, as related by al-Bukhāri.

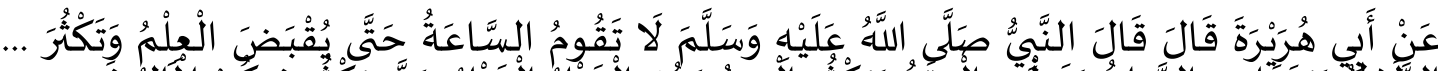

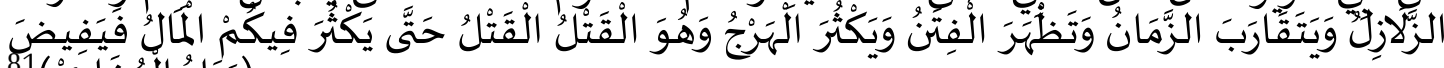

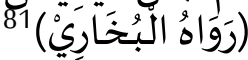

Translation:

...from Abu Hurairah r.a., he said, the Prophet said: "The Day of Judgment will never come except after the loss of knowledge, the occurrence of many earthquakes, when time seems to pass very quickly, widespread of slander, alharaj, that is, murder and abundance of wealth."(Hadith related by al-Bukhari)

a. The explanation of the hadith about the signs of doomsday in the book of the Ministry of Religious Affairs of the Republic of Indonesia entitled Kiamat

${ }^{74}$ Bashiruddin, Mekanika Hari Kiamat dan Hidup Sesudah Mati (Bandung: Pustaka, 1992 M.), p. 52.

75 See A. Zainuddin dan Muhammad Jamhari, al-Islām I: Akidah dan Ibadah (Bandung: Pustaka Setia, 1999 M.), p. 299.

${ }^{76}$ Aḥmad ibn Muștafā al-Marāghì, Tafsì al-Marāghī, vol XXX (Egypt: Syirkah Maktabah wa Maṭba'ah Muștafāa al-Bābī al-Ḥalabī, 1365 H./1946 M.), h. 218.

${ }^{77}$ See; Ahmad Sonhadjo Mohamad, Tafsir al-Qur'an, Juz XXX (Kuala Lumpur: Pustaka alMizan, 1992 M.), p. 175.

${ }^{78} \mathrm{Abu}$ al-Fidā' Ismā'il ibn 'Umar ibn Kas̄ìr al-Qurasyī, Tafsīr al-Qur'ān al-'Azīim, p. 441.

${ }^{79}$ See; Sayyid Qutb, Tafsir di Bawah Lindungan al-Qur'an, trans. Siti Rabi'ah Sarnap, vol XXX (Johor Bahru: Perniagaan Jahabersa, 2008 M.), p. 389.

${ }^{80}$ Sayyid Quṭb Ibrāhīm Ḥusain al-Syārabī, Fì Zilāl al-Qur'ān, vol VI (Bairūt-Khairo: Dār alSyurūq,1412 H.), p. 3955.

${ }^{81}$ Muhammad ibn Ismā’ìl Abū 'Abdillāh al-Bukhārì al-Ju’fí, Saḥịh al-Bukhārī, vol II, p. 33. 
dalam Perspektif al-Qur'an dan Sains ${ }^{82}$ describes some of the aspects mentioned above. The loss of knowledge and extensive ignorance. The term knowledge in this context is not intended for general science, as nowadays there are more people who are experts in technology and science. What is actually meant is the science of religion. Therefore scholars interpret the phrase "loos of knowledge" or "disappearance of science" with the reduction of religious teaching. There are also some scholars who interpret it as the increasing number of scholars who die, ${ }^{83}$ while the next generation cannot reach the awareness level of the previous generations. This brings about widespread ignorance and finally, the community asks questions related to religion to people who were not experts. Thus there arises chaos in the religious council, which leads to heresy and deception. This case is explained in a hadith related by al-Bukhārī.

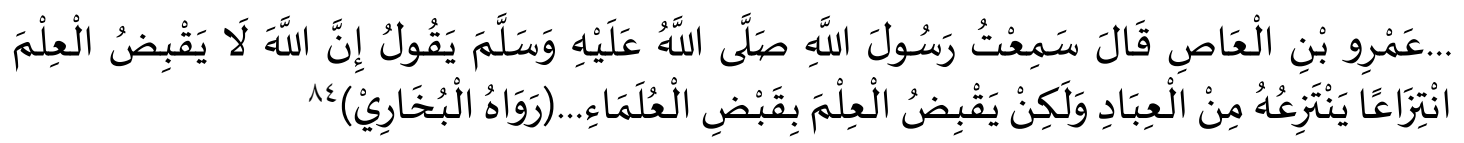

Translation:

...from 'Amrū ibn al-'Ās r.a., he said, the Prophet said: "Surely Allah does not pull up knowledge directly from a servant, but Allah withdraws the knowledge by way of taking the lives of the religious scholars (Hadith related by A1Bukhari).

b. The increasing number of deaths or murders. This can be felt in the period after the Prophet passed away. There will be wars between the Muslims themselves. Today, wars between one nation and another are increasingly prevalent. Human life seems no longer meaningful at the end of time, it is very cheap.

c. The extensive circulation of liquor and adultery ${ }^{85}$ This is evident by the excess of liquor and drugs which even became a big problem for the world community, in addition to the widespread of adultery.

d. A lot of insults and earthquakes. Insults here mean great toughness in one's life that religion is often explained without mindful consideration. ${ }^{86}$

The hadith which makes the object of the study above explains some signs of the end of time, namely the loss of knowledge, occurrences of earthquakes, time

\footnotetext{
${ }^{82}$ Kementerian Agama RI., Kiamat dalam Perspektif al-Qur'an dan Sains (Jakarta: Lajnah Pentashihan Mushaf al-Qur'an, 1432 H./2011 M.), p. 49-50.

${ }^{83} \mathrm{Abū}$ Muḥammad Maḥmūd ibn Aḥmad ibn Mūsā ibn Aḥmad ibn Ḥusain al-Ghītābì alHanafĩ Badr al-Dīn al-'Aini, 'Umdah al-Qārī' Syarh Saḥịh al-Bukhārī, vol VII, p. 57.

${ }^{84}$ Muḥammad ibn Ismā'il Abū ‘Abdillāh al-Bukhārì al-Ju’fí, Saḥịh al-Bukhārī, Juz I, h. 31.

${ }^{85}$ See; 'Awạ̣ ibn 'Ali ibn 'Abdullāh, Mukhtașar Asyrāt al-Sā'ah al-Sughrā wa al-Kubrā, terj. Muh. Khairuddin Rendusara, Tanda-tanda Hari Kiamat Besar dan Kecil (Islamhouse, 1430 H./2009 M.), p. 9-23.
}

${ }^{86}$ Kementerian Agama RI., Keniscayaan Hari Akhir (Jakarta: Lajnah Pentashihan Mushaf alQur'an, 1431 H./2010 M.), p. 170-188. 
passes fast, many kinds of insults and abundant wealth arise. To the researcher's opinion, the phrase "loss of knowledge" is not meant to be limited to the declining knowledge of religion. This view is different from the perspective in the book Kiamat dalam Perspektif al-Qur'an dan Sains written by the Ministry of Religious Affairs. ${ }^{87}$ Furthermore, the researcher saw that in the hadith and its explanation the kind of knowledge that will disappear was not mentioned, so in this context, there is no dichotomy between religious and general science as long as the existence of the science brings about benefits to human beings.

The next sign of the end of the world is that "there are many earthquakes." Scholars generally understand the word الزََّزَزْن to mean a shock to the earth. ${ }^{88}$ Nevertheless, there are also those who interpret it as a shock that occurs in the human heart. In the researcher's view, the earthquake in question is intended to mean the movement of the earth's crust or the earth's plate resulting in a disaster. This view is supported by the verses of the Qur' an and the hadith which speak of the signs of the Day of Judgment, mostly referring to the shocks that occur on the earth. Furthermore, to the researcher's analysis, the signs mentioned in the hadith above are small signs of the end of the world, because these events have occurred since ancient times, although still on a minimum scale.

There are many signs before the occurrence of the Day of Judgment contained in some hadith, such as in the one related by Abū Dāwud.

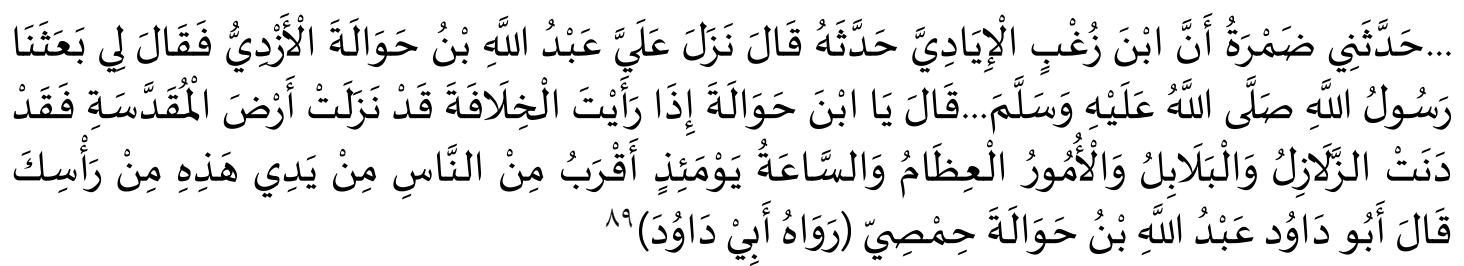

Translation:

...told us, Damrah told me that Ibn Zughb al-'Iyā told him, he said; 'Abdullah ibn Hawa àl-Azdi stopped by at my place, then he said to me; The Messenger of Allah ..." O son of Hawalah, when you see the Caliphate has descended on the sanctified earth, it is indeed near to the disaster of the earthquake and many kinds of sorrows and great affairs. At that time the Judgment Day is closer to the people than my hand from my head." Abu Daud said; Abdullah ibn Hawalah is a Hims. (Hadith related by Abu Dawud).

The above hadith explains about the sign of the Day of Judgment, namely "if the Caliphate has descended on sanctified earth," this wording is very ambiguous that the scholars explain that the intention is from Medina to the land of Sham, as

${ }^{87}$ Objek ilmu yang dimaksud ialah ilmu agama. See; Kementerian Agama RI., Kiamat dalam Perspektif al-Qur'an dan Sains, p. 49-50.

${ }^{88}$ Aḥmad ibn Muḥammad ibn Abī Bakr ibn 'Abd al-Mālik al-Qasṭalānī al-Qutaibì al-Miṣrī, Irsyād al-Särī li al-Syarh Șậ̣̣̣ al-Bukhārī, vol II, p. 256.

${ }^{89}$ Abū Dāwud Sulaimān ibn al-Asy'as ibn Isḥāq ibn Basyīr ibn Syaddād ibn 'Amrū al-Azadi al-Sijistānì, Sunan Abī Dāwud, vol III, p. 19. 
during the Umayyad rule. Some understand it as only the land of Sham. ${ }^{90}$ When the incident occurs, the earthquake is near and so are also the various kinds of sadness and big affairs. At that point in time, the end of the world has become very close. The phrases that indicate signs of doomsday are earthquakes and big affairs. ${ }^{91}$ Hence the end of time described above is still classified as small signs of doomsday because such an incident has long been valid. The same is true of the following hadith which also explains the small signs of the Day of Judgment, as the in hadith related by Ahmmad.

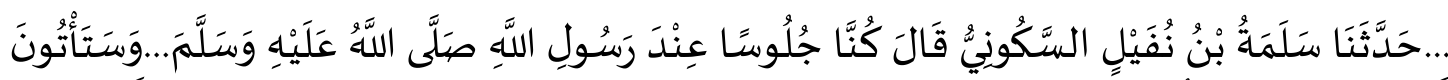

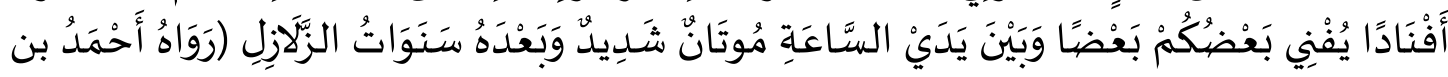

Translation:

...he said Salamah ibn Nufail al-Sakuni said; We were sitting at the side of the Messenger of Allah. Then there was a man who said: "O Messenger of Allah ... You will come to a group that is splitted and their people are destroying each other. Before the Doomsday occurs, there will be a lot of terrible deaths and after that there will be a few years of shocks." (Hadith related by Ahmad).

The three hadiths that were the objects of previous studies only discuss the small signs of the coming of the doomsday. But the next hadith will describe as ashrät al-kubrä "great signs" of the coming of the Day of Judgment, as in the hadith related by Abū Dāwud.

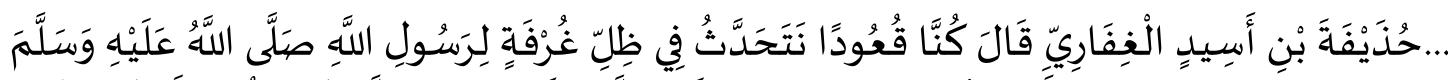

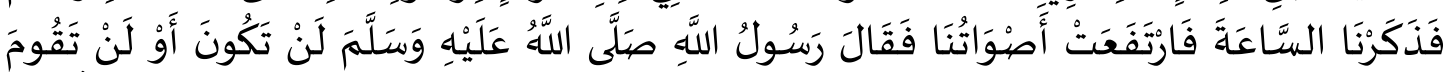

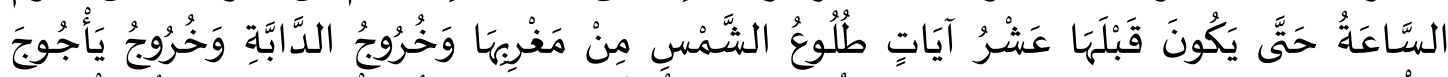

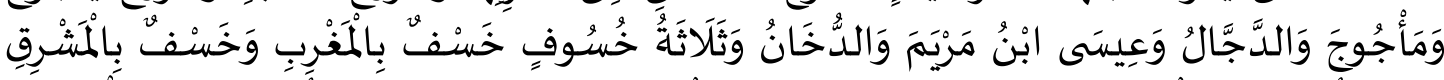

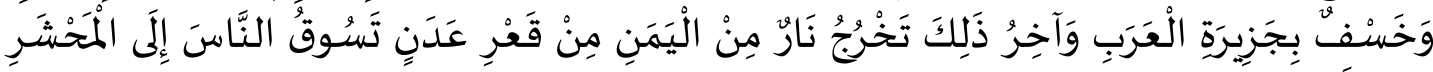

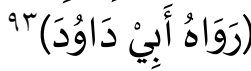

Translation:

${ }^{90}$ Abd al-Muhsin ibn Hamid ibn 'Abd al-Muḥsin ibn 'Abdillāh ibn Hamid ibn al-'Abbād alBadr, Syarh Sunan Abī Dāwud, vol XXI, p. 299.

${ }^{91}$ Meskipun ada pendapat bahwa gempa bumi menjadi awal mula terjadinya kiamat. See; 'Ali ibn Sulțān Muḥammad Abū al-Ḥasan Nūr al-Dīn al-Malā' al-Harawī al-Qārī, Mirqāh al-Mafătīh Syarḥ Misykäh al-Mașābīh, vol VIII, p. 3435.

${ }^{92} \mathrm{Abu}$ 'Abdillāh Aḥmad ibn Muḥammad ibn Ḥanbal ibn Hilāl ibn Asad al-Syaibānī, Musnad Ahmad ibn Hanbal, vol XXVIII, p. 163.

${ }^{93} \mathrm{Abu}$ Dāwud Sulaimān ibn al-Asy'as ibn Isḥāq ibn Basyīr ibn Syaddād ibn 'Amrū al-Azadì al-Sijistānī, Sunan Abī Dāwud, vol IV, p. 114. 
..from Huzaifah ibn Asid al-Ghifari. He said, "We sat together beside of the Prophet's room while talking about the Day of Judgment. Our voices were so loud that the Messenger of Allah p.b.u.h. said: "It will not happen, or no doomsday will come until ten signs appear: the rising of the sun from west, the emergence of crawling animals, the exit of Ya'uj and Ma'juj, Dajjal, the son of Mary, a smoke and three earthquakes (landslides), landslides in the west, east and in the Arabian Peninsula. And the last sign is the release of fire from Yemen, from the ground of "Adn which will lead people to the field of mahsyar." (Hadth related by Abū Dā wud).

The above hadith also explains about earthquakes as a sign of the end of the world. However, the earthquake that will occur at this point in time is the kind that has never been experienced by humans before. The earthquakes referred to in QS alZalzalah will occur all over the surface of the earth as the beginning of the

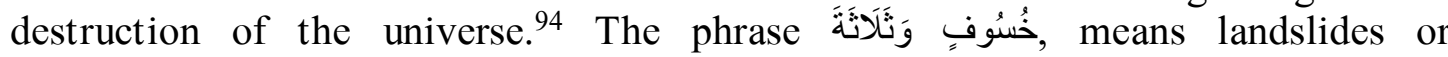
earthquakes will occur three times, that is, in the east, in the west, and in the Arabian Peninsula. At that time the surface of the ground will collapse to the bottom of the earth, the land that is apparent then becomes a hole. ${ }^{95}$ In the researcher's view, these ten big signs are intended for their literal meanings without any contextual connotation, as they are generally related to nat ural phenomena leading to the cycle of the end of the world.

\section{E. Conclusion}

The hadith which is the object of study in this study amounted to seventeen hadith and the researcher divides into ten themes of discussion. All the traditions that are the object of research have sanad and matan which are considered valid (in this case include hasan traditions), except for one tradition whose quality is daif on the theme of the earthquake sign of damage to people's lives.

Earthquake events according to the Prophet's hadith. contains several meanings which include theology, sociology, and science. The translation of the three sciences is as follows. Earthquakes in the form of natural phenomena are said by previous scholars as large animals in the bowels of the earth so that with the development of science it is known that there are geological activities that cause vibrations. In addition, the capacity of the Holy Prophet. as an apostle also cannot be ruled out, because the information about the earthquake is not able to reach the minds of humans in general, so humans must believe as a revelation, for example, the earthquake that occurred in the future at Najed, the cessation of the mountain shook when the Prophet ordered to stop, the earthquake became a help God and the characteristics of earthquake-prone areas.

Earthquakes can also mean non-physical shocks, although there are differences of opinion because they still consider shocks to the earth, for example, the end earthquake of the prosperity of the Muslims, the end-time earthquake in

${ }^{94}$ Ahmad Sonhadji Mohamad, Tafsir al-Qur'an, vol XXX (Kuala Lumpur: Pustaka al-Mizan, 1992 M.), p. 175.

${ }^{95 \prime}$ Abd al-Muhsin ibn Hamid ibn 'Abd al-Muḥsin ibn 'Abdillāh ibn Ḥamid ibn al-'Abbād alBadr, Syarh Sunan Abī Dāwud, vol XXV, p. 484. 
Medina and the earthquake as a punishment for the world. In addition, earthquakes are a sign of the destruction of social life and signs of doomsday. Thus in the Prophet's hadith. Includes ten meanings of an earthquake and can occur if one of the ten events has already appeared. 


\section{BIBLIOGRAPHY}

Al-Qur'an al-Karim.

Abdurrahman. "Mukjizat al-Qur'an dalam berbagai Aspeknya". Jurnal Pustaka Media Kajian dan Pemikran Islam 8. (2016): h. 69.

Abha, Muhammad Makmun. "Gempa Bumi dalam al-Qur'an (Tafsir Tematik)". Jurnal Esensia 14. no. 1 (April 2013): h. 29-31.

Abū 'Isā, Muhammad ibn 'Isā ibn Sūrah ibn Mūsa ibn Ḍaḥhāk al-Tirmižìi. Sunan alTirmiżīi. Cet. II; Mesir: Syirkah Maktabah wa Maṭba'ah Mușțafã al-Bābī alHualabì, 1395 H./1975 M.

Ahmad, Arifuddin. Metodologi Pemahaman Hadis Kajian Ilmu Ma’ānī al-Hadiss. Cet. II. Makassar: Alauddin University Press, 2013 M.

Al-'Ainī, Abū Muhammad Mahmūd ibn Ahmad ibn Mūsā ibn Ahmad ibn Husain al-

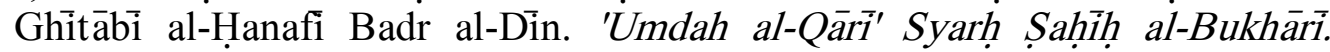
Bairūt: Dār Ihyā' al-Turāè al-'Arabī, t.th.Hendratno, Agus. "Kumpulan Materi: Pengenalan Bencana Alam Tanah Longsor", Yogyakarta: PDF Program, 2007 M.

Al-Aṣfahānī, Al-Rāghib. Mu'jam Mufahras Alfāz al-Qur'ān. Bairūt: Dār al-Fikr, t.th.

Al-Azharīi, Muḥammad ibn 'Abd al-Bāqi' ibn Yūsuf al-Zarqāni al-Mișrì. Syarḥ alZarqānī 'alā Muwatta' al-Imām Mālik. Cet. I. al-Qāhirah: Maktabah alSaqāfah al-Dīniyah, 1424 H./2003 M.

Al-Badr, 'Abd al-Muhsin ibn Ḥamid ibn 'Abd al-Muhsin ibn 'Abdillāh ibn Ḥamid ibn al-'Abbād. Syarḥ Sunan Abī Dāwud. Cet. II; Bairūt: Dār al-Kutub al-'Ilmiyah, $1415 \mathrm{H}$.

Al-Badr,'Abd al-Muhsin ibn Ahmad ibn 'Abd al-Muhsin ibn 'Abdillāh ibn Ahmad ibn Hamid al-'Ab̉̄ād Fad̆l al-Madinah wa Adāb Sakinahā wa Ziyārahă. Cet. I. Mața'ah al-Narjiz, 1421 H./2000 M.

Al-Baghdāđì, Zain al-Dīn 'Abd al-Rahmān ibn Ahmad ibn Rajab ibn al-Ḥasan alSalāmì. Fatḥ al-Bârì Syarḥ Sahịh al-Bukhârì. Bairūt: Dār al-Ma'rifah, 1379 H.

Al-Haddāđīi, Zain al-Dīn Muhammad al-Mad'ū Ba'bad al-Ra'ūe ibn Tāj al-'Ārifín ibn 'Ali ibn Zain al-'Ābidin. al-Taisīr bi Syarḥ al-Jāmi' al-Saghîr. Cet. II; alRiyād:: Maktabah al-Imām al-Syāfi'i, 1408 H./1998 M.

Al-Ḥusainī, Muhammad Rasyīd ibn 'Alì Riḍā ibn Muhammad Syams al-Dīn ibn Muhammad Bahā' al-Dīn ibn Manlā'Khalifah al-Qulamūnì. Tafsīr al-Qur'ān al-Ḩakìm (Tafsìr al-Manār). Khairo: Dār al-Manār, 1967 M.

Al-Ju'fí, Muhammad ibn Ismā'îl Abū 'Abdillāh al-Bukhārī Sahịịh al-Bukhārì. Cet. I. Dār ai-Ṭauq al-Najāh, $1422 \mathrm{H}$.

Al-Mahalli, Jalāl al-Dīn Muḥammad ibn Aḥmad dan Jalāl al-Dīn 'Abd al-Raḥmān ibn Abì Bakr al-Suyūṭị. Tafsìir Jalālain. Cet. I. al-Qāhirah: Dār al-Ḥadis̀, t.th.

Al-Mahalli, Jalāl al-Dīn Muhammad, Tafsir Jalalain. Beirut: Dār al-Fikr, 1989 M. 
Al-Marāghī, Ahmad ibn Muștafā Tafsīir al-Marāghī. Cet. I. Mesir: Syirkah Maktabah wa Maṭba'ah Muștafä al-Bābì al-Halabì, 1365 H./1946 M.

Al-Mișrī, Aḥmad ibn Muḥammad ibn Abì Bakr ibn 'Abd al-Mālik al-Qasțalānī alQutaibī. Irsyād al-Sārì li al-Syarh Saḥịh al-Bukhārì. Cet. VII; Mesir: alMațba'ah al-Kubrā al-Amiriyah, $1323 \mathrm{H}$.

al-Naisābūìi, Abū 'Abdillāh al-Ḥākim Muḥammad ibn 'Abdillāh ibn Muhammad ibn Hamdūyah ibn Nu'aim ibn Hakim al-Dabì. Mustadrak 'alā al-Sahịhain. Cet. I. Bairūt: Dār al-Kutub al-'Ilmiyah, 1411 H/1990 M.

Al-Naisābūrì, Abū al-Ḥusain Muslim ibn al-Ḥajjāj ibn Muslim al-Qusyairì. Sahịihh Muslim. Bairūt; Dār al-Kutub al-'Ilmiyah, 1992 M.

Al-Nasā'ì, Abu 'Abd al-Rahmān Ahmad ibn Syu'aib ibn 'Ali al-Khurāsānì. al-Sunan al-Sagri li al-Nasā'î. Cet. III. Halb; Maktab al-Maṭū'àt al-Islāmiyah, 1406 $\mathrm{H} / 1986 \mathrm{M}$.

Al-Qārī, 'Ali ibn Sulțān Muhammad Abū al-Hasan Nūr al-Dīn al-Malā' al-Harawī. Mirqāh al-Máătīh Syarh Misykāh al-Mașābīh. Cet. I. Bairūt-Libanōn: Dār alFikr, 1422 H./2002 M.

Al-Qardawi, Yūsuf Halal dan Haram dalam Islam. terj. Saleh Mahfoed. Bandung: alMa'ärif, t.th.

Al-Qurasyìi, Abū al-Fidā' Ismā̄il ibn 'Umar ibn Kas̄ìr. Tafsìr al-Qur'ān al-'Azìim. Cet. I. Bairūt: Dār al-Kutub al-'Ilmiyah, $1419 \mathrm{H}$.

Al-Qurțubì, Muḥammad ibn Aḥmad al-Anșārì. al-Jāmi' li Ahkām al-Qur'ān. Khairo: Dār al-Kutub al-'Arabiyah, 1378 H./1967 M.

Al-Sabauni, Syaikh Muhammad Ali Gerak dan Rotasi Bumi. Jakarta: Dar al-Kutub al-Islamiyah, $2003 \mathrm{M}$.

Al-Syāfi'í, Muhammad 'Ali ibn Muhammad ibn Ghilān ibn Ibrāhīm al-Bakrī al-

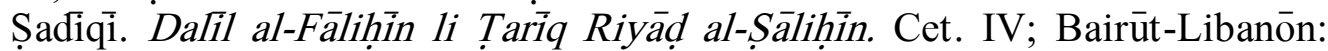
Dār al-Ma'rifah li al-Ṭaba'ah wa al-Nasyr wa al-Tauzi', 1425 H./2004 M.

Al-Syārabī, Sayyid Quṭb Ibrāhìm Ḥusain fỉ Zilāl al-Qur'ān. Cet. XVII; BairūtKhairo: Dār al-Syurūq, $1412 \mathrm{H}$.

Al-Syaibānì, Abū 'Abdillāh Ahmad ibn Muhammad ibn Hanbal ibn Hilāl ibn Asad. Musnad Aḥmad ibn Hanbal. Cet. I. Muassasah al-Risālah, 1421 H./ 2001 M.

Al-Syaqawī, Syaikh Amīn ibn 'Abdillāh. Fadāil al-Madinah wa Haramātihā. Terj. Abu Umamah Arif Hidayatullah, Keutamaan Madinah. Islamhouse, 1435 h./2013 M.

Al-Tabarì, Muhammad ibn Jarì ibnYazīd ibn kasīi ibn Ghālib al-Amli Abū Ja'far. Tärikh al-Rusul wa al-Muluk. Bairūt: Dār al-Turās, $1387 \mathrm{H}$.

Al-'Usaimīn, Muḥammad ibn Șāliḥ ibn Muhammad. Syarḥ Riyạ̣̄ al-Sāliḥin. alRiyād: Dār al-Watan li al-Nasyr, $1426 \dot{\mathrm{H}}$.

Al-Ya'qubī, Aḥmad ibn Ya'qūb. Tärikkh al-Ya'kubī.t.tp.: t.p., t.th.

Arifin, Bey. Mengenal Tuhan. Surabaya: PT. Bina ilmu, t.th. 
Badan Koordinasi Nasional Penanggulangan Bencana. Pengenalan Karakteristik Bencana dan Upaya Mitigasinya di Indonesia. ed. Triutomo. Dkk. Jakarta: Direktorat Mitigasi Lakhar Bakornas PB, 2007 M.

Bashiruddin. Mekanika Hari Kiamat dan Hidup Sesudah Mati. Bandung: Pustaka, $1992 \mathrm{M}$.

Basiron, Noor Fazilah Mohd. "Fenomena Gempa Bumi: Tinjauan Awal Terhadap Kewujudannya dalam al-Qur'an". Jurnal Islam dan Masyarakat Kontemporari 9. (Januari 2015): h. 142.

Bund, Arbiater Samariter. Handout Kesiapan Sekolah dalam Menghadapi Bencana. Yogyakarta: Arbiater-Samariter-Bund, $2008 \mathrm{M}$.

Departemen Agama RI., Pelestarian Lingkungan Hidup. Cet. I. Jakarta: Lajnah Pentashihan Mushaf al-Qur'an, 1431 H./2010 M.

Dewan Redaksi. Ensiklopedi Islam. Cet. I. Jakarta: PT Ichtiar Baru Van Hoeve, 1993 M.

Hadhiri SP, Choiruddin. Klasifikasi Kandungan al-Qur'an. Jakarta: Gema insani Press, $1993 \mathrm{M}$.

Hijazi, Muhammad Mahmud. Fenomena Keajaiban al-Qur'an: Kesatuan Tema dalam al-Qur'an. Jakarta: Balai Pustaka, 2005 M.

Ibn 'Abd al-Mālik, ibn Bațtāl Abū al-Hasan 'Alì ibn Khalf. Syarh Saḥịh al-Bukhārī li ibn Battāàl. Cet. II; al-Su'ūdiyah al-Riyād: Maktabah al-Rusyd, 1423 H./2003 M.

Ibn 'Abdullāh, 'Awaḍ ibn 'ATi. Mukhtașar Asyrāt al-Sä'ah al-Sughrā wa al-Kubrā. Terj. Muh. Khairuddin Rendusara, Tanda-tanda Hari Kiamat Besar dan Kecil. Islamhouse, 1430 H./2009 M.

Ibn al-As̄ìr, Abū al-Hasan 'Alì ibn Abì al-Karim Muhammad ibn Muhammad 'Abd alKarìm ibn 'Ábd al-Wāhid al-Syaibānì al-Jazirì 'Iz al-Dīn. al-Kāmil fī alTărikh. Cet. I. Bairūt: Libanōn, 1997 M.

Ibn Bāz, Syaikh 'Abd al-'Azīz ibn 'Abdullāh. Nașịhah Haul al-Zalāzil. Terj. Syafar Abu Difa. Nasehat Seputar Gempa. Islamhouse, 1430 H./2009 M.

Ibn Qazwīīi, ibn Mājah Abū 'Abdillāh Muhammad ibn Yazìd Sunan Ibn Mājah. Dār al-Kutub al-'Arabiyah, t. th.

Jasmi, Kamarul Azmi. Geologi Hidrologi, Oceanografi dan Astronomi dari Perspektif al-Qur'an. Cet. I. Malaysia: UTM Press, 2013 M.

Kementerian Agama RI. Keniscayaan Hari Akhir. Cet. I. Jakarta: Lajnah Pentashihan Mushaf al-Qur'an, 1431 H./2010 M.

Kiamat dalam Perspektif al-Qur'an dan Sains. Cet. I. Jakarta: Lajnah Pentashihan Mushaf al-Qur'an, 1432 H./2011 M.

Mohamad, Ahmad Sonhadji. Tafsir al-Qur'an. Kuala Lumpur: Pustaka al-Mizan, $1992 \mathrm{M}$.

Mohd Basiron, Noor Fazilah dan Munirah Abd Razzak "Rujukan al-Qur'an dan alHadith dalam Penelitian Fenomena Gempa Bumi. Jurnal Ushuluddin. (Malaysia: PDF Program, $2012 \mathrm{M}$. 
Qutb, Sayyid. Tafsir di Bawah Lindungan al-Qur'an. Terj. Siti Rabi'ah Sarnap. Johor Bahru: Perniagaan Jahabersa, $2008 \mathrm{M}$.

Ratnasari, Dwi. "Sejarah Nabi-Nabi dalam al-Qur'an”, Komunika, Vol. 5, no.1, (2011), h. 98.

Shihab, M. Secercah Cahaya Ilahi Hidup Bersama al-Qur'an. Edisi Ke-2. Cet. I. Bandung: Mizan, 1434 H./2013 M. . Wawasan al-Qur'an Tafsir Tematik atas Pelbagai Persoalan Umat. Edisi Ke-2. Cet. II; Bandung: Mizan, 1435 H./2014 M. Mukjizat al-Qur'an. Bandung: Mizan, 1997 M.

Sudibyo, Muh. Ma'rufin. Ensiklopedi Fenomena Alam dalam al-Qur'an. Solo: Tinta Medina, $2012 \mathrm{M}$.

Sulaiman, Ahmad Mahmud. Tuhan dan Sains. Jakarta: PT. Serambi Ilmu Semesta, $2001 \mathrm{M}$.

Suswanto. "Mukjizat al-Qur'an". Jurnal Edu Religi 2. no.1 (2018): h. 30-33.

Syuhair bi al-Māwardi, Abū al-Ḥasan 'Ali ibn Muhammad ibn Muhammad ibn Habīib al-Bașìi al-Baghdādi. Tafsìr al-Māwardì. Bairūt-Libanōn: Dār al-Kutub al'Ilmiyah, t.th.

Tim Penyusun Kamus Pusat Pembinaan Bahasa Indonesia. Kamus Besar Bahasa Indonesia. Jakarta: Balai Pustaka, $1991 \mathrm{M}$.

Zainuddin, A. dan Muhammad Jamhari. al-Islām I: Akidah dan Ibadah. Bandung: Pustaka Setia, 1999 M.

Zamri, Ahmad Muhaimin ibn Mohd. "Relevansi Sains dengan Makna Zalzalah dalam al-Qur'an (Kajian Tafsir Tematik). Skripsi. Riau: Fak. Ushuluddin UIN Sultan Syarif Kasim, 2013 M. 


\section{Guidelines}

\section{Submission of Article}

urnal Adabiyah welcomes the articles submission with the main themes on Humanities and Islamic Studies with the emphasis on interdisciplinary and intertextuality approach. Adabiyah is thematicly published twice in a year. ie the theme of the humanities in June and the Islamic Study in December.

Themes related to Islamic Studies are textual studies, scriptural traditions, Islamic law, and theology; and those related to Humanities are language, literature, history, and culture. This scholarly journal Guarantees that the editor decision based on the peer review results will not exceed 30 days from the paper submission date.

Authors are invited to read our archives; to find the relevant topics for the journal, and to submit complete unpublished scientific researches, which are not under review in any other conferences or academic journal.

\section{PUBLICATION ETHIC}

Publication Ethic and Malpractice Statement

Jurnal Adabiyah is a peer-reviewed journal, published twice a year by the Faculty of Adab and Humaniora, Alauddin State Islamic University of Makassar Indonesia. It is available online as open access sources as well as in print. This statement clarifies ethical behaviour of all parties involved in the act of publishing an article in this journal, including the author, the editor-in-chief, the Editorial Board, the reviewers, and the publisher. This statement is based on COPE's Best Practice Guidelines for Journal Editors.

Ethical Guideline for Journal Publication

The publication of an article in Jurnal Adabiyah, is an essential building block in the development of a coherent and respected network of knowledge. It is a direct reflection of the quality of the work of the authors and the institutions that support them. Peer-reviewed articles support and embody the scientific methods. It is therefore important to agree upon standards of expected ethical behavior for all parties involved in the act of publishing: the author, the editor, the reviewer, the publisher, and the society. As the publisher of Jurnal Adabiyah, the Faculty of Adab and Humaniora takes its duties of guardianship over all stages of publishing seriously and it recognizes its ethical and other responsibilities. The Faculty of Adab and Humaniora committed to ensuring that advertising, reprint or other commercial revenue has no impact or influence on editorial decisions.

\section{Publication Decisions}

The editors of Jurnal Adabiyah is responsible for deciding which articles submitted to the journal should be published. The validation of the work in question and its importance to researchers and readers must always drive such decisions. The editors may be guided by the policies of the journal's editorial board and constrained by such legal requirements as shall then be in force regarding libel, copyright infringement, and plagiarism. The editors may confer with other editors or reviewers in making their decisions.

\section{Plagiarism Screening}

It is basically author's duty to only submit a manuscript that is free from plagiarism and academically malpractices. The editor, however, will check all submitted papers through Turnitin.

\section{Fair Play}

An editor at any time evaluates manuscripts for their intellectual content without regard to race, gender, sexual orientation, religious belief, ethnic origin, citizenship, or political philosophy of the authors. 


\section{Confidentiality}

The editors and any editorial staff must not disclose any information about a submitted manuscript to anyone other than the corresponding author, reviewers, potential reviewers, other editorial advisers, and the publisher, as appropriate.

\section{Disclosure and Conflicts of Interest}

Unpublished materials disclosed in a submitted manuscript must not be used in editors' own research without the express written consent of the author.

\section{DUTIES OF AUTHORS}

\section{Reporting Standards}

Authors of reports of original research should present an accurate account of the work performed as well as an objective discussion of its significance. Underlying data should be represented accurately in the paper. A paper should contain sufficient detail and references to permit others to replicate the work. Fraudulent or knowingly inaccurate statements constitute unethical behaviour and are unacceptable.

\section{Originality and Plagiarism}

The authors should ensure that they have written entirely original works, and if the authors have used the work and/or words of others that this has been appropriately cited or quoted.

\section{Multiple, Redundant, or Concurrent Publication}

An author should not in general publish manuscripts describing essentially the same research in more than one journal or primary publication. Submitting the same manuscript to more than one journal concurrently constitutes unethical publishing behaviour and is unacceptable.

\section{Acknowledgement of Sources}

Proper acknowledgment of the work of others must always be given. Authors should cite publications that have been influential in determining the nature of the reported work.

\section{Authorship of the Paper}

Authorship should be limited to those who have made a significant contribution to the conception, design, execution, or interpretation of the reported research. All those who have made significant contributions should be listed as co-authors. Where there are others who have participated in certain substantive aspects of the research project, they should be acknowledged or listed as contributors. The corresponding author should ensure that all appropriate co-authors and no inappropriate co-authors are included on the paper, and that all co-authors have seen and approved the final version of the paper and have agreed to its submission for publication.

\section{Disclosure and Conflicts of Interest}

All authors should disclose in their manuscript any financial or other substantive conflict of interest that might be construed to influence the results or interpretation of their manuscript. All sources of financial support for the project should be disclosed.

\section{Fundamental errors in Published Works}

When an author discovers a significant error or inaccuracy in his/her own published work, it is the author's obligation to promptly notify the journal editor or publisher and cooperate with the editor to retract or correct the paper.

\section{PLAGIARISMI}

It is basically author's duty to only submit a manuscript that is free from plagiarism and academically malpractices. The editor, however, will check all submitted papers through Turnitin. 


\section{AUTHOR GUIDELINES}

\section{Guidelines for online submission:}

1. Author should first register as Author to the website of Jurnal Adabiyah. Click the menu "register" to register as an author.

2. Once after the author is registered, please login to the website of Jurnal Adabiyah and submit the article through online submission (with the stat us of active submissions).

3. The article should follow the standard template of Jurnal Adabiyah provided in the website.

4. The citation and bibliography should follow the Turabian citation style.

5. Author is restricted not to send his/her article to another journal before having confirmation from the editorial team (approximately 4 weeks right after the article submitted).

6. Author should follow editorial decisions and recommendations related to the article completion. All reviews and assessements will be informed through online submission.

Article submitted to Jurnal Adabiyah editorial board must follow these guidelines:

1. Article should be based on the scientific research in the field humanities and Islamic studies;

2. Article must be an original work and has not been previously published;

3. Article should be written in Arabic or English languages;

4. Article must be typed in one-half spaced on A4-paper size;

5. Article's length is about $6,000-10,000$ words;

6. All submission must include a 150-250 word abstract;

7. Abstract should be written in 3 languages; Arabic, English, and Bahasa;

8. Full name(s) of the author(s) must be stated, along with his/her/their institution and complete address;

9. All submission should be in OpenOffice, Microsoft Word, RTF, or WordPerfect document file format;

10. Bibliographical reference must be noted in footnote and bibliography according to Jurnal Adabiyah style. In addition, it is suggested for author(s) to use reference manager tools such as 30 MENDELEY or 2 otero

When a source is cited for the first time, full information is provided: full name(s) of author(s), title of the source in italic, place of publication, publishing company, date of publication, and the precise page that is cited. For the following citations of the same source, list the author's last name, two or three words of the title, and the specific page number(s). The word ibid., op.cit., and loc.cit. are may not be used any more.

\section{Example in footnotes:}

${ }^{1}$ Mircea Eliade (ed.), The Encyclopedia of Religion, vol. 8 (New York: Simon and Schuster, 1995), h. 18.

${ }^{2}$ Norman Daniel, Islam and the West (Oxford: One World Publications, 1991), h. 190.

${ }^{3}$ Syeikh Ja'far Subhānī, Mafăhim Al-Qur'ān (Beirut: Mu'assasah Al-Tarikh Al-'Arabī, 2010)., Juz 5, h. 231. 
${ }^{4}$ Syeikh Ja'far Subhānī, Mafăhim Al-Qur'ān, h. 8-9.

\section{Example in bibliography:}

Subhānī, Syeikh Ja'far. Mafāhim Al-Qur'ān. Beirut: Mu'assasah Al-Tarikh Al-'Arabī, 2010.

Eliade, Mircea (ed.). The Encyclopedia of Religion, vol. 8. New York: Simon and Schuster, 1995.

Daniel, Norman. Islam and the West. Oxford: One World Publications, 1991.

Shihab, Muhammad Quraish. Sunnah-Syiah Bergandengan Tangan: Mungkinkah? Kajian Atas Konsep Ajaran Dan Pemikiran. Cet. III. Jakarta: Lentera Hati, 2007.

Detail informations of the footnotes:

1. Holy book

Al-Qur'ân, Al-Baqarah/2: 185.

Perjanjian Baru, Mrk. 2: 18.

2. Qur'anic translation

${ }^{1}$ Departemen Agama RI, al-Qur'an dan Terjemahannya (Jakarta: Darus Sunnah, 2005), h. 55.

3. Book

${ }^{1}$ Muḥammad 'Ajjaj al-Khațib, Ușl al-Hadith: 'Ulumuh wa Mușțalaḥuh (Beirut: Dâr al-Fikr, 1989), h. 57.

4. Translation Books

${ }^{1}$ Toshihiko Izutsu, Relasi Tuhan dan Manusia: Pendekatan Semantik terhadap al-Qur'an, terj. Agus Fahri Husein dkk (Yogyakarta: Tiara Wacana, 2003), h. 14.

5. Voluminous book

${ }^{1}$ Muḥammad al-Ṭâhir b. 'Ashur, al-Tạnn̄̄r wa al-Tanwīr, Vol. 25 (Tunisia: Dâr al-Suhûn, 2009), h. 76.

${ }^{1}$ Muḥammad b. Ismā‘īl al-Bukharī, al-Jami` al-Ṣahịḥ, Vol. 2 (Beirut: Dar al-Kutub al-‘Ilmìyah, 1999), h. 77.

6. Article in book

${ }^{1}$ Sahiron Syamsuddin, "Metode Intratekstualitas Muhammad Shahrur dalam Penafsiran al-Qur'an" dalam Abdul Mustaqim dan Sahiron Syamsuddin (eds.), Studi al-Qur'an Kontemporer: Wacana Baru Berbagai Metodologi Tafsir (Yogyakarta: Tiara Wacana, 2002), h. 139.

7. Article in encyclopaedia

${ }^{1}$ M. Th. Houtsma, "Kufr” dalam A. J. Wensinck, at al. (ed.), First Encyclopaedia of Islam, Vol. 6 (Leiden: E.J. Brill, 1987), h. 244.

8. Article in journal

${ }^{1}$ Muhammad Adlin Sila, "The Festivity of Maulid Nabi in Cikoang, South Sulawesi: Between Remembering and Exaggerating the Spirit of Prophet", Studia Islamika 8, no. 3 (2001): h. 9.

9. Article in mass media

${ }^{1}$ Masdar F. Mas'udi, "Hubungan Agama dan Negara", Kompas, 7 Agustus 2002. 
10. Article in Internet

${ }^{1}$ Muhammad Shahrūr, "Reading the Religious Teks: a New Approach" dalam http://www.shahrour.org/25 Februari 2010/diakses 5 Juni 2010.

11. Thesis or dissertation

${ }^{1}$ Syahruddin Usman, "KinerjaGuru Penddikan Agama Islam pada SMAN dan SMKN Kota Makassar”, Disertasi (Makassar: PPs UIN Alauddin, 2010), h. 200.

\section{COPYRIGHT NOTICE}

Authors who publish with this journal agree to the following terms:

1) Authors retain copyright and grant the journal right of first publication with the work simultaneously licensed under a Creative Commons Attribution License that allows others to share the work with an acknowledgement of the work's authorship and initial publication in this journal.

2) Authors are able to enter into separate, additional contractual arrangements for the non-exclusive distribution of the journal's published version of the work (e.g., post it to an institutional repository or publish it in a book), with an acknowledgement of its initial publication in this journal.

3)Authors are permitted and encouraged to post their work online (e.g., in institutional repositories or on their website) prior to and during the submission process, as it can lead to productive exchanges, as well as earlier and greater citation of published work (See The Effect of Open Access). 